\title{
PORTO ALEGRE COMO DESTINO: VESTÍGIOS DE INICIATIVAS DE ATIVAÇÃO TURÍSTICA A PARTIR DA LITERATURA PARA VISITANTES
}

\author{
Maurício Ragagnin Pimentel * \\ Antonio Carlos Castrogiovanni **
}

\begin{abstract}
Resumo
O turismo é uma invenção do século XVIII que se articula como um sistema de alcance global em contínua expansão e transformação (ANTONESCU \& STOCK, 2014). 0 objetivo deste texto é examinar como Porto Alegre (RS) passa a fazer parte do Sistema Turismo. Ao longo do tempo, quais foram as iniciativas para habilitar esse território ao Olhar do Turista (URRY, 2001)? Como a articulação da função turística em Porto Alegre se altera com a evolução urbana da cidade e interage com outros impulsos urbanizadores que ali se produzem? Como tais iniciativas locais refletem movimentos, ou tendências, mais amplas do que é entendido por Turismo? Esta pesquisa exploratória está centrada na análise de um século da literatura produzida para visitantes, um corpus de 135 documentos, tais como guias de viagem, folhetos, catálogos e matérias na imprensa. Identificou-se e cinco arranjos do turismo neste destino, a saber: do enquadramento em cânones turísticos à Exposição do Centenário Farroupilha (1935); "Porto Alegre: cidade de turismo" e o Guia Touring Club (1945 e 1955); Turismo como função do poder público, Embratur e Epatur em 1978; Abertura econômica e a Administração Popular (1989-2004) e Copa do Mundo (2005-2015). Propõe-se a caracterização e análise dos quatro primeiros, em que se evidencia o caráter histórico e situado do desenvolvimento da função turística nesta metrópole regional, em um processo marcado por avanços, retrocessos, intermitências e, sobretudo, periférico a outros interesses que pautam a produção do espaço urbano.
\end{abstract}

Palavras Chave: História do Turismo. Turismo Urbano. Guias de Viagem. Porto Alegre (RS).

\section{PORTO ALEGRE AS A TOURISM DESTINATION: TRACES OF TOURISM ENABLING INITIATIVES IN THE LITERATURE DIRECTED TO VISITORS}

Tourism is an XVIII century invention that articulates a system with a global reach that is continuously changing and in expansion (ANTONESCU \& STOCK, 2014). This study seeks to examine how Porto Alegre (southern Brazil), begins participate at this system. Over time, which were the initiatives to enable this territory as an object of the 'tourist gaze' (URRY, 2001)? How does tourism relates with the city's urban evolution? How does it goes with other local urbanizing drives? How such particular initiatives reflect broader trends in what is understood by tourism? This exploratory research is based on the analysis of corpus of 135 documents encompassing over a century of the literature directed to visitors, such as travel guides, brochures, and press articles. It is proposed a characterization of five tourism sets in this destination throughout time, which are: from Porto Alegre's framing in tourist canons until Farroupilha's century exhibition (1935); "Porto Alegre: city of tourism" and the Touring Club guide (1945 and 1955); Tourism as public sector duty, Embratur and Epatur at 1978; the opening of economy and the Administração Popular (1989-2004); and the FIFA World Cup (2005-2015). The development of tourism in this regional metropolis answers to situated and historical characteristics, in a process distinguished by breakthroughs, setbacks, discontinuities, and, above all, marginal to other interests that set Porto Alegre's urban space production.

Keywords: Tourism History. Urban Tourism. Tourist Guides. Porto Alegre (Brazil).

\section{PORTO ALEGRE CÓMO DESTINO TURÍSTICO: HUELLAS DE LAS INICIATIVAS DE ACTIVACIÓN TURÍSTICA DESDE LA LITERATURA PARA VIAJEROS}

El turismo es una invención del siglo XVIII que se articula en un sistema de alcance global en continua expansión y transformación (ANTONESCU \& STOCK, 2014). El objetivo planteado en este texto es examinar como Porto Alegre (en el sur de Brasil) pasa a hacer parte del Sistema Turismo. ¿A lo largo del tiempo, cuáles fueron las iniciativas para habilitar este territorio a la 'mirada del turista' (URRY, 2001)? ¿Cómo en Porto Alegre la función turística se altera de acuerdo con la evolución urbana de la ciudad? ¿Cómo interactúa el turismo con los otros impulsos urbanizadores allí producidos? ¿Cómo tales iniciativas locales reflejan movimientos, o tendencias, más amplias de lo que es comprendido por Turismo? Esta investigación exploratoria está centrada en el análisis de un siglo de literatura producida para viajeros, un corpus de 135 documentos, tales como guías de viaje, folletos, catálogos y materias de prensa. Se propone la caracterización del turismo en este destino en cinco conjuntos, a saber: del encuadre en los cánones turísticos a la Exposición del Centenario Farroupilha (1935); "Porto Alegre: ciudad de turismo" y la guía del Touring Club (1945 y 1955); Turismo como función del poder público, Embratur y Epatur en 1978; así cómo la abertura económica y la Administração Popular (1989-2004); y Mundial de fútbol (2005-2015). Se evidencia el carácter histórico y situado del desarrollo de la función turística en esta metrópoli regional, en un proceso marcado por avances, retrocesos, intermitencias y, sobretodo, periférico a otros intereses que pautan la producción de su espacio urbano.

Palabras clave: Historia del turismo. Turismo urbano. Guías turísticos. Porto Alegre (Brasil).

\footnotetext{
* Doutor em Geografia / UFRGS. Mestre em Geografia / UFRGS. Bacharel em Turismo / PUCRS. Professor Adjunto da FURG. Pesquisador do Laboratório da Paisagem PAGUS / UFRGS. CV: http://lattes.cnpq.br/1786556571533985. Universidade Federal do Rio Grande. Instituto de Ciências Humanas e da Informação, Curso de Turismo. R. Glicério P. de Carvalho, 81. CEP 9623-000, Santa Vitória do Palmar/RS, Brasil [mauricioragagnin@gmail.com]

** Doutor em Comunicação Social / PUCRS. Mestre em Educação / UFRGS. Bacharel em Geografia / UFRGS. Professor Associado da UFRGS, Programa de Pós-Graduação em Geografia e Faculdade de Educação. Professor Adjunto da Escola de Humanidades / PUCRS. CV: http://lattes.cnpq.br/7721027764504488. Universidade Federal do Rio Grande do Sul, Instituto de Geociências, Programa de Pós-Graduação em Geografia. Av. Bento Gonçalves, 9500 Prédio 43113/203, Campus Vale. CEP 9154-000, Porto Alegre/RS, Brasil.[castroge@ig.com.br]
} 


\section{INTRODUÇÃO}

Para o historiador Boyer (2003, p. 14): "[...] nenhum lugar é 'turístico em si', nenhum sítio 'merece ser visitado', como diz a literatura turística; o Turismo é um produto da evolução sociocultural [...]". Considerando tal assertiva, este texto analisa como historicamente se constitui o turismo em Porto Alegre, capital do Rio Grande Sul.

$O$ trabalho apresenta um interesse duplo. Por um lado, considera as diferentes iniciativas e arranjos locais mobilizados para atender essa intencionalidade, ou "olhar do turista" (URRY, 2001), sendo uma história do turismo em Porto Alegre. Mas, ao estudar como esse território se torna objeto dessa intencionalidade e suas variações ao longo do tempo, também é possivel traçar uma história do turismo situada a partir de Porto Alegre. Assim, é um estudo de caso que permite identificar elementos da evolução do próprio turismo, seus entendimentos, inovações e tendências gerais.

Este trabalho dialoga com uma abordagem teórico-epistemológica recente do turismo de origem francófona. A partir do estudo da emergência do turismo no tempo e no espaço, esses autores (ÉQUIPE MIT, 2005; ANTONESCU e STOCK, 2014; 2014a) propõem sua compreensão enquanto sistema. No entanto, ao partir de uma abordagem indutiva, essa é uma proposta de análise sistêmica distinta daquelas de caráter estruturalista, como a Beni (2003) ou Boullón (2006).

A renovação do interesse por práticas turísticas em cenários urbanos, e o debate sobre Turismo Urbano (DUHAMEL, 2007; 2007a; SELBY, 2004; SPIROU, 2011; GRAVARI-BARBAS, 2013; JANSENVERBEKE, 2009; HAYLLAR e GRIFFIN, 2011) é o outro ponto de interesse teórico.

Este estudo de caso exploratório e descritivo sobre a evolução do turismo em Porto Alegre, foi realizado a partir de uma pesquisa documental. A partir de busca sistemática houve a composição de um corpus com 135 documentos que são testemunho e também reflexo das iniciativas de ativação turística da cidade. A análise desse corpus foi cotejada com pesquisa bibliográfica sobre a evolução urbana de Porto Alegre (ALONSO; BANDEIRA, 1988; PESAVENTO, 1999; DE SOUZA e MÜLLER, 2007; SINGER, 1968).

Como resultado, há proposta de periodização da função turística na cidade em cinco arranjos, a saber: do enquadramento em cânones turísticos à Exposição do Centenário Farroupilha (1935); "Porto Alegre: cidade de turismo" e o Guia Touring Club (1945 e 1955); Turismo como função do poder público, Embratur e Epatur em 1978; abertura econômica e Administração Popular (1989-2004); e Copa do Mundo (2005 -2015).

Evidencia-se o caráter histórico e situado do acolhimento e desenvolvimento da função turismo nesta metrópole. É um processo marcado por avanços, retrocessos, intermitências, e, sobretudo, em diálogo e competição com outros interesses que pautam a produção do espaço urbano da capital gaúcha. No entanto, é necessário marcar que há uma permanência da intencionalidade turística sobre cidade, apesar das variações de sua articulação neste sistema global de destinos, da perda da função turística de alguns pontos de seu território, ou do desempenho da gestão do destino.

As particularidades do turismo em Porto Alegre tecem um nó na trama que é o sistema turismo global, em que cada elo da tecedura é único, uma articulação particular com especificidades de cada local e de sua relação com o conjunto da trama. No entanto, nota-se que Porto Alegre traduz regionalmente elementos de tendência mais geral sobre o turismo nas cidades. Exemplo disso é o discurso turístico centrado na modernidade, no patrimônio cultural e na produção de eventos, elementos que Duhamel (2007a) já identificava como apelo das metrópoles no século XIX, ou ainda, iniciativas como a reconversão de espaços centrais em equipamentos culturais, a criação de centros de eventos e a produção de eventos (GRAVARI-BARBAS, 2013; SPIROU, 2011).

Este texto está organizado do seguinte modo: há uma breve revisão teórica dos pressupostos do que está sendo considerado por turismo e implicações de seu caráter histórico e de articulador global. Posteriormente, é discutido o caráter urbano do turismo e a emergência de uma produção teórica sobre práticas turísticas no cenário das cidades, em particular metrópoles. A seção metodológica expressa algumas escolhas e posicionamentos realizados neste estudo, sobretudo a respeito do tipo discursivo Literatura Turística. Finalmente está a descrição das principais características dos arranjos de articulação da função turismo em Porto Alegre em relação à evolução urbana da cidade e dinâmica do Sistema Turismo global. Nas considerações finais destacamos as implicações teóricas e práticas dos resultados, apontamos limitações deste estudo e possibilidades para investigações futuras.

\section{TURISMO: UM SISTEMA EM EVOLUÇÃO QUE ARTICULA O MUNDO}

Duhamel (2013) e Cuvelier (2010) situam a invenção do Turismo na Inglaterra entre 1700 e 1740, durante a primeira revolução industrial. Entendendo 
por Turismo um sistema de práticas, lugares e atores que visa à re-criação dos indivíduos (ÉQUIPE MIT, 2005). Produto da modernidade, o turismo representa uma revolução de consequências semelhantes à industrial (ÉQUIPE MIT, 2011). Desde sua emergência, tem se transformado, em um processo que passa a englobar novos locais, novos comportamentos, novos significados e a associar agentes diversificados.

Antonescu \& Stock (2014) propõem uma análise empírica da evolução do Sistema Turismo ao acompanhar suas transformações e expansão por meio de guias de viagem. Os autores concluem que "desde o começo do século XIX os padrões espaciais do Turismo mudaram radicalmente: de um sistema compreendendo um pequeno número de lugares para um sistema global de locais turísticos" (ANTONESCU e STOCK, 2014, p. 77).

A constatação da historicidade do Turismo traz implicações epistemológicas importantes. Um exemplo é a crítica à noção de 'vocação' turística, ou à tese funcionalista do Turismo, como resultante da necessidade de escape das pressões cotidianas e inerente carência do verde por parte das sociedades industriais. Outra implicação é considerar as particularidades da articulação e posição de cada destino neste sistema, afastando-se da leitura etapista de suas dinâmicas e evolução, como a do ciclo de vida de Butler (1980).

Os locais são atravessados pelo turismo de diferentes modos, com implicações e composições distintas, em uma diversidade de tipos urbanos. 0 sistema global turismo não é uniforme, mas espacialmente e temporalmente diferenciado. Os elementos dessa interconexão -ou a 'liga da maionese', na metáfora de Violier (2008) - variam em cada destino. Os arranjos turísticos variam, fortalecendo-se ou debilitando-se, o que não implica a ausência de certas regularidades, como atesta a tipologia espacial de Duhamel (2003) e Équipe MIT (2011).

Como prática sociocultural, o turismo tem origem e caráter eminentemente urbano (KNAFOU, 2007; PIMENTEL e CASTROGIOVANNI, 2016; PIMENTEL, 2009). São as cidades os primeiros locais a constituírem-se em destinos (URBAIN, 2002; ÉQUIPE MIT, 2005). Por concentrarem os equipamentos de hospedagem, "emerge[m] como uma ilha acolhedora no universo dos viajantes" (URBAIN, 2002, p. 182). No período entre os séculos XVI e XVIII quando existia não mais que um proto-Turismo (ÉQUIPE MIT, 2005), eram as cidades que figuravam nos relatos das coisas vistas por mercadores, diplomatas, prelados e outros escassos viajantes 0 campo e os espaços não povoados, ao contrário, eram sinônimo de perigo, da natureza hostil e da ausência de 'algo digno de nota'.
A sensibilidade estética que iria despertar fluxos para novas paisagens, conotadas como pitorescas ou sublimes (LÖFGREN, 2006) era ainda incipiente. No século XIX, o movimento centrípeto em direção à cidade se inverte, com a expansão da industrialização e 0 crescimento das urbes ganha vigor o discurso antiurbano (URBAIN, 2002). A cidade é percebida como um local com ausência de beleza, poluído, barulhento, pestilento, em que se acumulam problemas sociais: um câncer moderno. Uma nova inflexão do interesse turístico pelas cidades, em especial metrópoles, passa a ocorrer nos últimos quarenta anos.

Spirou (2011) descreve o processo em que 0 desenvolvimento das novas Tecnologias de Informação e Comunicação (TICs), o barateamento dos custos de transportes e a integração de diferentes mercados estimulou a (re)organização das empresas em rede. Nesse contexto de mobilidade facilitada as organizações passam a buscar vantagens locacionais. Isso desencadeia a descentralização, flexibilização e dispersão de distintas atividades produtivas implicando em um movimento de relativa desindustrialização das metrópoles de sua progressiva especialização no setor terciário.

A presença de áreas abandonadas permite projetos de refuncionalização e novos investimentos nos centros urbanos. $O$ papel da imagem e do marketing também adquire certa proeminência para cidades que competem pelos investimentos desse capital móvel - no que Harvey (2006) denomina cidade empreendedora.

O Turismo, tradicionalmente associado à fuga da cidade industrial, torna-se um signo de urbanidade e de centralidade dessa cidade terciária simbolizada pela festa, multiculturalidade e poder (GRAVARIBARBAS, 2013). Mesmo em destinos tradicionais, como as capitais européias, a proposta de políticas específicas de turismo é algo da década de 1990 (VIOLIER e ZARATE, 2007).

As cidades procuram tornarem-se turísticas promovendo seus lugares, manifestações e paisagens enquanto elementos dignos de capturar 0 Olhar do Turista (URRY, 2001). Algumas iniciativas nesse sentido são: a criação de equipamentos lazer, ou a realização de intervenções urbanas, a exemplo de ícones arquitetônicos ou da realização de eventos; mas também a produção de uma imagem da cidade enquanto destino turístico através da publicidade e promoção, bem como a ativação e valorização turística de seu patrimônio (GRAVARI-BARBAS, 2013; SELBY, 2004; SPIROU, 2011).

Mesmo cidades tradicionalmente industriais com demanda calcada na mobilidade corporativa, buscam diminuir os efeitos da sazonalidade e rentabilizar os 
investimentos feitos em uma estrutura receptiva através da diversificação de sua oferta. Um processo em que a existência de serviços turísticos e a capacidade de atrair visitantes, interessados na diversidade de opções de descoberta, de jogo, de entretenimento e de consumo, torna-se uma medida de sua importância enquanto nó da rede global.

Tal movimento é seguido por um interesse teórico, como aponta Jansen-Verbeke (2009) na Encyclopedia of Tourism editada por Jafar Jafari. 0 verbete indica a emergência do campo de estudos sobre Turismo Urbano a partir de 1980. De modo geral os temas em destaque neste campo são: a distribuição espacial do turismo e a configuração de áreas funcionais especializadas (tourism precints), ou em um tom crítico, os processos de gentrificação e segregação espacial evidenciados por tais espaços; as estratégias de city marketing e a produção de imaginários para atração de visitantes, bem como as contestações sobre sua autenticidade e a mercantilização de culturas e identidades.

Outro campo de investigação são os efeitos das intervenções urbanas e megaeventos que têm 0 turismo como subterfúgio, e os reflexos de suas articulações no plano da política, das finanças e da produção do espaço urbano. Hayllar (2011) Selby (2004) e Spirou (2011), são exemplos de obras que buscam compilar e sintetizar as discussões atuais sobre o turismo em cidades.

Cabe apontar, no entanto, que apesar de ser um termo consagrado na busca de compreender as peculiaridades do desenvolvimento do turismo tendo as cidades como cenário, a expressão Turismo Urbano é imprecisa. Isso porque todo turismo é produto de uma sociedade urbana e um vetor de sua expansão (DUHAMEL, 2007; PIMENTEL e CASTROGIOVANNI, 2016) e assim não alcança a diversidade de situações da relação entre urbano e turismo. Como comparar uma metrópole como uma estação balneária? Qual posição das cidades médias na relação entre hierarquia urbana e turismo? São questões meditadas na tipologia de Duhamel (2003) e Équipe MIT (2011).

Tendo em vista esse interesse teórico sobre o Turismo Urbano, aliado a uma preocupação por entendê-lo a partir de uma perspectiva histórica e situada no Sistema Turismo, é que este trabalho se propõe a analisar o caso de Porto Alegre, entendida como "uma cidade polivalente que dispõe da função turística como uma entre outras" (VIOLIER e ZARATE, 2007, p. 146). Isso a coloca junto com locais investidos pelo turismo, distintos de locais criados pelo turismo e de locais subvertidos pelo 0 turismo, em que esse opera transformação da dinâmica produtiva, tornando-se essencial, como Gramado (RS), por exemplo.

\section{METODOLOGIA: 0 TIPO DISCURSIVO LITERATURA TURÍSTICA COMO FONTE DE PESQUISA}

Esta pesquisa de caráter exploratório e descritivo é um estudo de caso. A principal estratégia de investigação é a pesquisa documental (FLICK, 2009), triangulada com a revisão bibliográfica sobre 0 desenvolvimento urbano de Porto Alegre. Para Flick (2009) a pesquisa documental pressupõe um processo de busca e de seleção, pautada em critérios como autenticidade, credibilidade, representatividade e significação, visando à formação de um corpus. Maingueneau $(2015$, p. 40$)$ define corpus como um "conjunto de textos agrupados para responder a um questionamento explícito".

A constituição do corpus analisado ocorreu partir de uma busca sistemática em bibliotecas, arquivos, livrarias de obras usadas (sebos) e fontes online, resultando em um conjunto de documentos da literatura turística cujo referente é Porto Alegre. Foram encontrados um total de 135 documentos que formam a coleção investigada, abrangendo um período de cem anos, de 1915 a 2015, embora em uma distribuição não uniforme. Foi realizada uma análise interna de cada documento, inspirada na Teoria Fundamentada (STRAUSS e CORBIN, 2008) e sua triangulação com o conjunto do corpus.

Duas questões de referência nesta análise foram: quais os arranjos daquele território e tempo cristalizados em cada proposta de acolhimento aos visitantes? Quais características do Sistema Turismo de cada época que estão expressos em cada documento? Neste processo foi possível identificar algumas fontes que se destacaram pela riqueza de informações e detalhes, condensando aspectos de um conjunto mais amplo, enquanto outras eram mais sintéticas. É a diferença, por exemplo, do Guia 4 Rodas de 1965 (ABRIL, 1965), em que é apresentada apenas uma lista com nomes e hierarquização de alguns atrativos, em contraste com o Guia Embratur de 1978 em que há um texto introdutório sobre a história da cidade, descrições de cada ponto turístico, ilustrações em bico de pena, além de um relato o processo de elaboração do guia.

A regra para seleção dos documentos foi 0 pertencimento a um tipo discursivo, isto é, textos que designam "práticas discursivas ligadas a um mesmo setor de atividade, agrupamentos de gêneros estabilizados por uma mesma finalidade social" (MAINGUENEAU, 2015, p. 66), ao qual denominamos por Literatura Turística (LT).

Entende-se aqui por LT os textos cujo públicoalvo são os visitantes de determinado espaço, embora não necessariamente a eles restritos. Tais 
textos têm como função servirem de apoio para estrangeiros em uma terra estranha e atuam como ferramentas para a descoberta e para prática turística de determinado espaço, além de promoverem lugares e imaginários particulares.

Essa definição fez com que não fossem considerados para análise textos que apesar de apresentarem a cidade, muitas vezes aproximando-a de cânones turísticos, fossem veiculados a públicoalvo de habitantes de Porto Alegre, como é o caso da Revista do Globo ${ }^{1}$, ou imprensa local. Como tipo discursivo, a LT inclui diferentes gêneros discursivos (MAINGUENEAU, 2015, p. 66), tais como: guias e relatos de viagem, cadernos de Turismo de jornais, revistas de bordo, mapas, encartes, folhetos distribuídos a visitantes, bem como, blogs, aplicativos e plataformas interativas da web 2.0 - embora estes últimos não tenham sido objeto desta investigação.

Embora não seja o único, pode-se considerar o guia de viagem como gênero emblemático desse tipo discursivo. Antonescu e Stock (2014, p. 5) destacam que os guias representam "o momento em que a função turística de um local é confirmada por um documento", em que há "o reconhecimento, por uma configuração constituída por turistas, editores e redatores de um local como sendo turístico" (ANTONESCU e STOCK, 2014, p. 5).

Como fonte de pesquisa existe a possibilidade, "portanto, de historicizar o Turismo e reconstruir a maneira como o espaço turístico foi imaginado em um dado momento. Trata-se de julgamentos sobre os locais geográficos que são contingentes, mas não arbitrários, e que mudam ao longo do tempo (ANTONESCU e STOCK, 2014, p. 7).

Considera-se que, se por um lado, tais sugestões estão relacionadas ao jogo que os turistas fazem de descobrir e relacionar-se com a alteridade, por outro, esse discurso também vincula-se ao modo que 0 público-alvo de visitantes é imaginado pelos autores dos textos. Ou seja, ali também é possivel identificar como é concebida a própria figura do turista e o papel atribuído ao turismo por aquela sociedade.

As indicações e as escolhas realizadas nos textos da LT são permeadas de implicações políticas, muitas vezes refletindo disputas da sociedade anfitriã. Esses discursos constituem a cristalização de arranjos de atores, objetos e intencionalidades, que resultam das iniciativas de atribuir-se uma denotação turística a determinado território, do qual são também a expressão. Seus enunciados são uma janela a partir da qual é possível reconstituir os cenários e os

\footnotetext{
1 Periódico ilustrado editado pela Livraria do Globo entre 1929 e
} 1967 que foi referência para a cena cultural Porto Alegrense propósitos que presidiram a proposição de tais diálogos entre visitantes e espaço visitado.

Por vezes, os guias, folhetos, brochuras e reportagens são os únicos rastros de projetos e iniciativas turísticas que tiveram lugar em um destino. Analisar as proposições da LT parece crucial para entender como um território se constitui em destino. Quais práticas e locais são sugeridos aos visitantes? Quais imaginários são evocados? Como esse território é inventado/inventariado por essa literatura? Quem se propõe a designar e endossar o que é considerado turístico em um destino? Essas são algumas das possibilidades de leitura e análise desses textos, além da consideração da distribuição cronológica de sua emergência. Contudo, neste texto o foco restringe-se aos arranjos que lhe produziram.

Além da análise documental desse corpus da LT sobre Porto Alegre, contribuiu para os resultados dessa pesquisa o processo de triangulação (FLICK, 2009) com outras fontes. A principal delas foi 0 resultado de uma revisão bibliográfica sobre a evolução urbana da cidade (ALONSO e BANDEIRA, 1988; DE SOUZA e MÜLLER, 2007; PESAVENTO, 1999; SINGER, 1968). Outra é o relato de Osvaldo Goidanich (1992), personagem importante para 0 desenvolvimento do Turismo no Rio Grande do Sul no século XX. Além da própria vivência dos autores que residem em Porto Alegre e já realizaram entrevistas com pessoas ligadas ao Turismo na cidade por conta de outros projetos de pesquisa.

\section{ANÁLISE}

\subsection{Objeto de Estudo}

O objeto desta pesquisa é o desenvolvimento do turismo situado em Porto Alegre, assim cumpre apresentar brevemente esse referente da LT investigada. A localização de Porto Alegre é apresentada na figura 1. Ela é considerada uma Metrópole Regional (IBGE, 2008), cuja economia, após um processo de desindustrialização, está baseada em atividades do setor terciário, que representam $85,3 \%$ dos 57,37 bilhões de reais de seu PIB (FEE, 2014). É 0 décimo maior município brasileiro em população, com 1,472 milhão de habitantes (FEE, 2014), e polo da quinta maior região metropolitana do Brasil, com população aproximada de 4 milhões de habitantes.

A sua curva de crescimento demográfico pode ser analisada na figura 2. Porto Alegre é um dos 65 destinos indutores do Ministério do Turismo, e está na classe A, na hierarquia do Mapa Brasileiro de Turismo, segundo o qual recebe anualmente 3,17 milhões de visitantes (BRASIL, 2018). 
Figura 1. Mapa com a localização de Porto Alegre (RS).

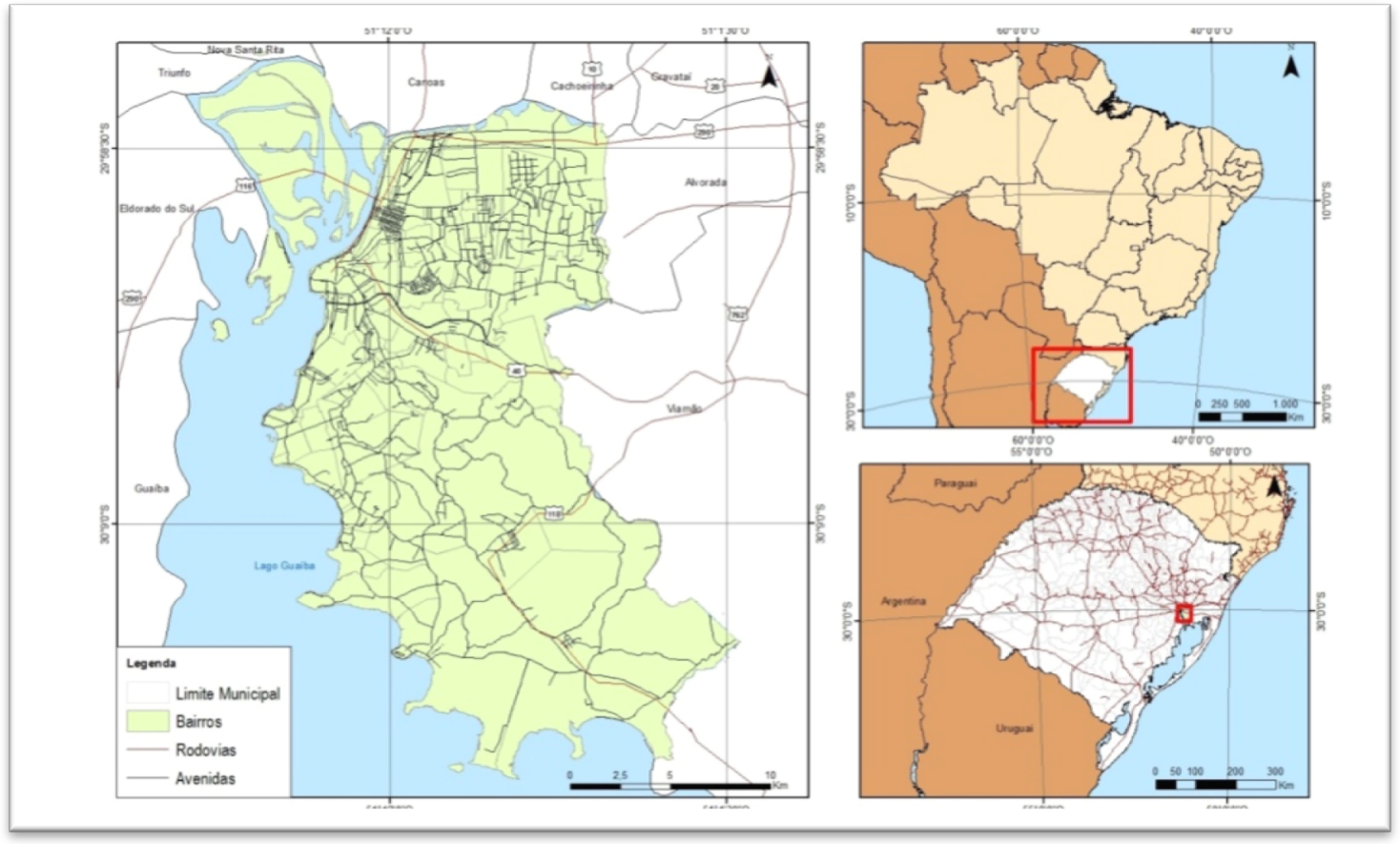

Fonte: elaboração dos autores.

Figura 2-Curva de crescimento demográfico do município de Porto Alegre.

\subsection{0 .000}

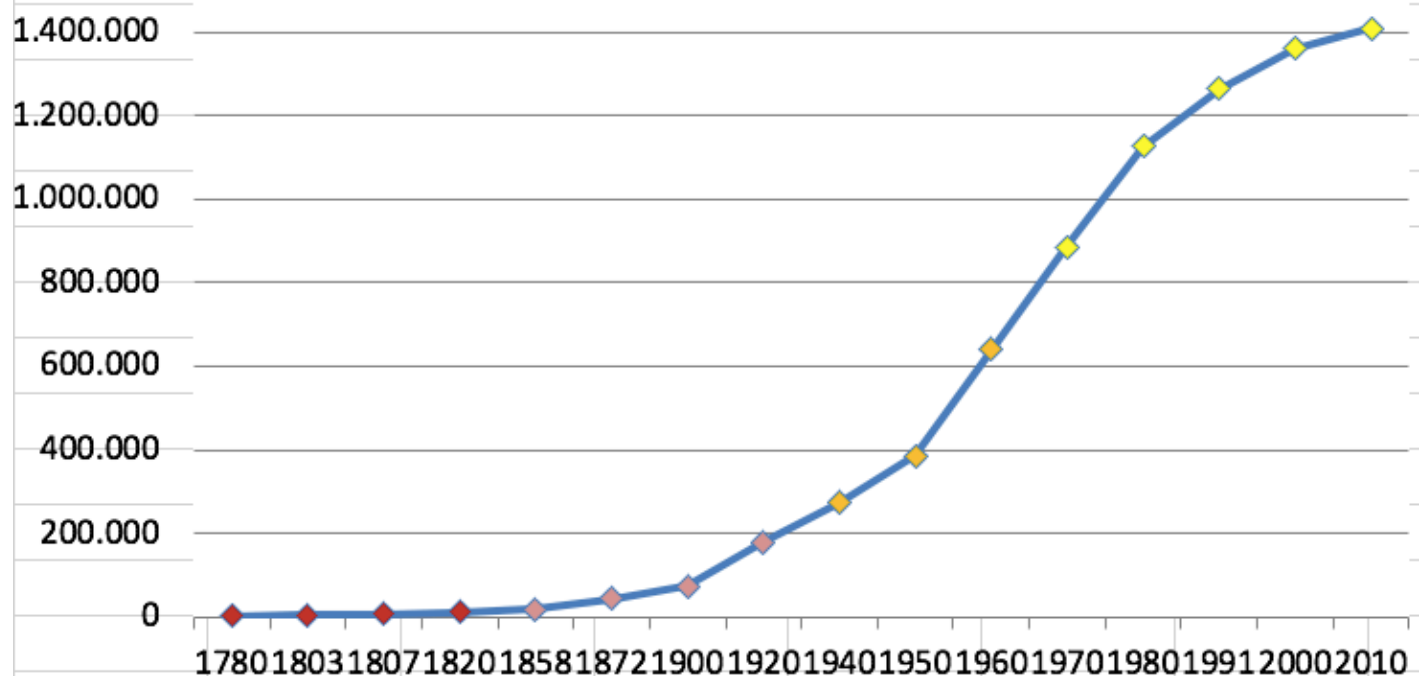

Fonte: elaborado pelos autores, baseado em De Souza e Müller (2007) até 1858, e Censo do IBGE (2017) de 1872 a 2010.

A curva de crescimento demográfico expressa as transformações pelas quais o município passou ao longo do último século, fruto do processo de industrialização, acolhimento do êxodo rural e especialização em serviços. É nesse o cenário em transformação que está a seguinte análise de modo como esse destino articula-se no Sistema Turismo e de como a função turismo se insere em seu território
4.2 Interpretação e Discussão: Porto Alegre no Sistema Turismo, uma proposta de diferentes temporalidades

Uma primeira aproximação da dimensão temporal do Turismo em Porto Alegre a partir do corpus estudado é avaliar as datas de produção desses documentos, o que pode ser visto no gráfico 1. 


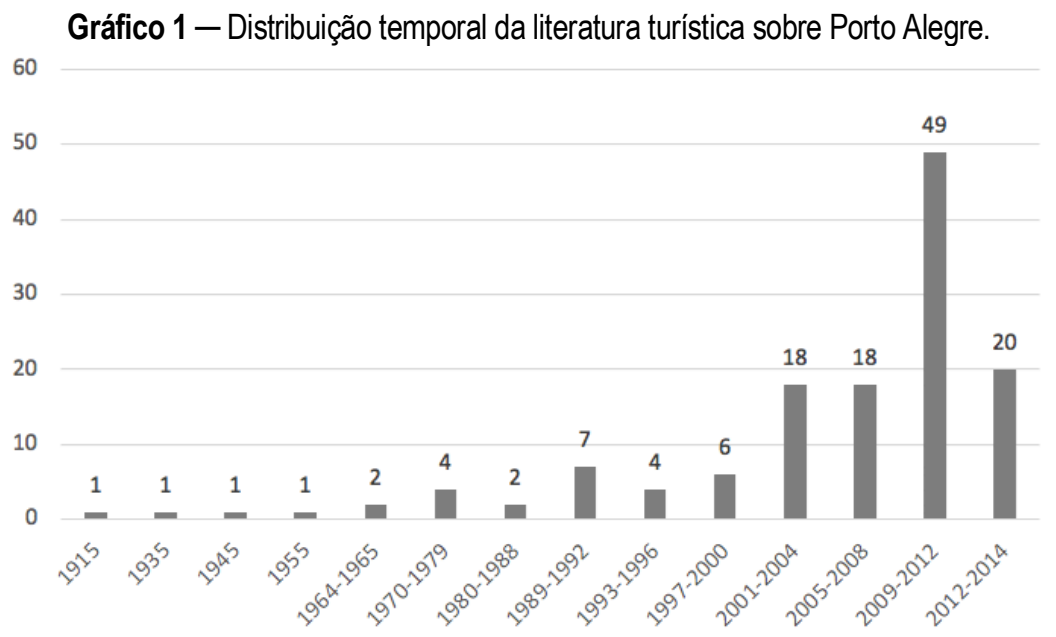

Fonte: elaborado pelos autores com base no corpus investigado.

Até os anos 1960 os documentos da LT são raros e frutos de iniciativas pontuais. Naquela década notase o fortalecimento de um Sistema Turismo doméstico com o lançamento do Guia Quatro Rodas (ABRIL, 1965) de edição e abrangência nacional, assim do Caderno Turismo do jornal Folha de São Paulo. Nos anos 1970 há engajamento de diferentes atores na promoção turística da cidade, particularmente entidades estatais responsáveis pelo turismo nas três esferas do executivo. Os anos 1980 são marcados por uma relativa escassez de testemunhos. A concentração de documentos a partir dos anos 1990 parece indicar uma mudança do próprio papel do Turismo na agenda política do município. Esse movimento faz eco ao contexto de mobilidade ampliada e de um contexto de competição urbana em um mundo globalizado em que há uma busca das cidades em inserirem-se. Aspectos comentados na produção teórica sobre Turismo Urbano discutida anteriormente.

Outrossim, diferentes indicadores corroboram a maior presença de visitantes à cidade a partir de então, como tamanho de sua oferta hoteleira e o fluxo em seu aeroporto. Apesar disso, é válido recordar que muitos desses documentos da LT investigada, como folhetos e catálogos, via de regra não são objeto de um protocolo de conservação e, tendo em vista as vicissitudes do tempo, essa abundância recente também pode refletir a maior probabilidade de documentos terem chegado até nós. É interessante considerar certas lacunas temporais em que há uma ausência de fontes, e refletir em que medida poderiam indicar uma certa intermitência, ou enfraquecimento, do Turismo na cidade.

Um segundo momento na aproximação a esse corpus foi o exame interno de cada documento em uma análise qualitativa inspirada na Teoria Fundamentada (STRAUSS e CORBIN, 2008) e sua posterior triangulação (FLICK, 2009), com o conjunto dos documentos. A partir dessa análise e tendo em vista o estudo das transformações da própria cidade, de sua situação frente ao conjunto do espaço em que interage e do Sistema Turismo como um todo, parecem emergir cinco momentos, ou arranjos, do Turismo em Porto Alegre, que são: do enquadramento em cânones turísticos à Exposição do Centenário Farroupilha (1935); "Porto Alegre: cidade de turismo" e o Guia Touring Club (1945 e 1955); Turismo como função do poder público, Embratur e Epatur em 1978; abertura econômica e Administração Popular (1989-2004); e Copa do Mundo (2005-2015).

Antes de caracterizar e discutir os quatro primeiros arranjos vale ressaltar que essa configuração está pautada nas características históricas de cada arranjo turístico cristalizado e não em uma distribuição cronológica uniforme das fontes. Outro ponto é que, até por sua escassez, essas fontes foram consideradas como janelas históricas para esses períodos, há assim o destaque para uma dimensão eventual, mais do que uma preocupação detida em estabelecer as fronteiras de continuidade e ruptura entre cada arranjo apresentado. Esse caráter pontual é mais presente nos três primeiros arranjos, nos dois últimos existe uma continuidade de documentos e uma ruptura política bastante clara a partir das quais já é possível uma avaliação do período de modo transversal.

É pertinente também considerar a distribuição temporal dos documentos da LT sobre Porto Alegre face à cronologia dos autores que estudam o Turismo Urbano e aos estudos sobre a articulação do Sistema Turismo. Sendo este um estudo de caso de caráter indutivo a proposta de periodização aqui realizada é reflexo de uma dinâmica local. No entanto, não deixa de refletir movimentos de abrangência mais ampla, tal como forte presença do Estado na década de 1970, o movimento de desindustrialização nos anos 1980 e de inserção em uma competição urbana, marcada pela abertura da economia brasileira e busca por descentralização administrativa, no final dos anos 1990 e início dos 2000. 
4.2.1 Do enquadramento em cânones turísticos à Exposição do Centenário Farroupilha (1915-1935)

Entende-se o Turismo como decorrência de uma prática cuja origem é situada no tempo e no espaço, cujos códigos e modos de perceber o mundo desenvolveram-se em paralelo a mobilidades de interesse científico, artístico e desportivo (BOYER, 2003; DUHAMEL, 2013; ÉQUIPE MIT, 2005; LÖFGREN, 2006; URRY, 2001).

Em diversas obras que tratam sobre a história do surgimento das práticas turísticas, a emergência de um olhar estético para o mundo é um marco importante. Há, com a modernidade, o desenvolvimento de uma cultura que percebe 0 espaço enquanto elemento provocador de emoções e que ao mesmo tempo desenvolve os sentidos. A conotação utilitarista, ou de medo do desconhecido, próprios da sociedade medieval, dão lugar à curiosidade moderna. Institucionalizam-se as vistas e o modo como devem ser apreciadas pelos visitantes (LEOTTA, 2005; URRY, 2001). Configura-se um processo em que a produção de códigos estéticos, determinando uma paisagemmatriz, retroage sobre a paisagem-marca (BERQUE, 1998), e progressivamente há uma expansão do maior número de lugares lidos desde tal matriz.

Também no caso de Porto Alegre os primeiros visitantes da cidade que nos legaram relatos vieram em expedições científicas, comerciais e militares. Não obstante, imiscuído a esses propósitos está 0 surgimento de um olhar estético sobre sua paisagem, seu enquadramento nos cânones turísticos por parte de um público estrangeiro Ocidental e a percepção de seu espaço como um campo para descoberta. Nesse sentido, vale a pena reproduzir a descrição da cidade publicada na revista American Naturalist, em abril de 1883. É interessante notar o esforço do narrador em traduzir Porto Alegre a partir de elementos de referência comum ao público leitor norte-americano.

"O Guaíba é muito pitoresco. Altos morros graníticos circundam a margem leste, por vezes despidos e precipitados, frequentemente com encostas gramadas e ravinas pontilhadas por florestas. Umas poucas ilhotas rochosas estão espalhadas sobre o canal, uma delas é usada como armazém de pólvora e estação de sinalização náutica, mas não existem fortificações. [...] 0 ponto sul é baixo e margeado por uma floresta pantanosa; o ponto norte, sobre - qual a cidade está construída, é um promontório granítico com certa de 150 pés de altura. Essa elevação, embora pequena, muito contribui para o caráter pitoresco do lugar; casas brancas e amareladas, com telhados vermelhos, são visitas elevando-se uma sobre a outra, e os prédios públicos coroam o morro com belo efeito.
Das cidades brasileiras essa é a menos tropical em aparência, a arquitetura mostra alguns traços daquele tipo romano degradado comumente visto na America espanhola e portuguesa, mas mesmo isso não é muito notável, na chegada nos poderíamos nos imaginar em uma cidade portuária dos Estados Unidos. As ruas são largas e bem pavimentadas com pórfiro dos morros adjacentes, mas eles são mal drenados e sujos - outro lembrete, talvez, de Nova lorque e Filadélfia. Casualmente encontramos hotéis excelentes e muito razoáveis em suas taxas; todos tem nomes italianos ou franceses, com que propósito seria difícil dizer, pois essas nacionalidades mal estão representadas na cidade. Existem ao redor de 35.000 habitantes, na maioria brasileiros brancos e alemães. [...]

Fizemos várias pequenas excursões ao entorno da cidade, notando as peculiaridades físicas da região e tomando nosso primeiro vislumbre de sua fauna e flora. Linhas de bondes correm em várias direções, permitindo pequenas excursões muito agradáveis, e além dessas existem boas estradas e caminhos pela beira do rio entre os morros e ravinas. Por toda parte há a mesma mescla de aspectos tropicais e temperados; pessoas, costumes, arquitetura, animais e plantas, o próprio ar, mudando de abafado para gelado no mesmo dia, mostrounos que estávamos em uma fronteira, que compartilha características de duas regiões." (SMITH, 1883).

A apreciação estética da paisagem, com ênfase em seu caráter pitoresco, a comparação com outras cidades na tentativa de interpretar 0 que era experimentado - em uma tentativa de traduzir 0 desconhecido para um novo público -, as excursões com o propósito de descobrir o espaço visitado, descritas como agradáveis, a percepção de Porto Alegre como alteridade particular, uma mistura entre tropical e temperado, a existência de equipamentos hoteleiros capazes de acolher visitantes; esses parecem ser elementos indicativos que estava em formação a intencionalidade turística sobre o espaço de Porto Alegre. Alguns desses aspectos são reproduzidos até hoje nos textos que visam dotar 0 visitante de chaves para interpretar esse destino turístico.

Esse relato era voltado ao público interessado nas expedições geográficas da época. Todavia, as primeiras publicações do gênero guia de viagens intencionadas para visitantes do continente sulamericano encontradas nesta pesquisa são da primeira década do século XX, o Land of the Southern Cross, de 1911, e o The Guide of South America, de 1915. Ambas escritas em inglês para um público norte- 
americano e europeu a fim de realizar o tour no continente ou estabelecer contatos comerciais.

O guia escrito por Hirst e publicado em Nova lorque em 1915 é a primeira menção encontrada sobre Porto Alegre enquanto destino turístico. Embora qualificada como uma 'attractive town, of over 100,00 inhabitants (HIRST, 1915, p. 142), o guia aponta "Não é muito provável que muitos viajantes queiram visitar o sul do Brasil. O clima é bom mas os objetos de interesse não são numerosos" (HIRST, 1915, p. 140). Visitar a região implicaria, de certa forma, um desvio da rota mais comum para se conhecer o continente.

Ambos os guias (CURRIER, 1911; HIRST, 1915) recomendam uma viagem de 120 a 180 dias, com a primeira parada no porto de Pernambuco. $O$ destaque da jornada era a Argentina - e o progresso do país então -, e depois a continuação se fazia pelo Oceano Pacífico e Canal do Panamá. O mapa da figura 3 ilustra a jornada:

Figura 3. Itinerário de viagem apresentado no guia Lands of the Southern Cross.

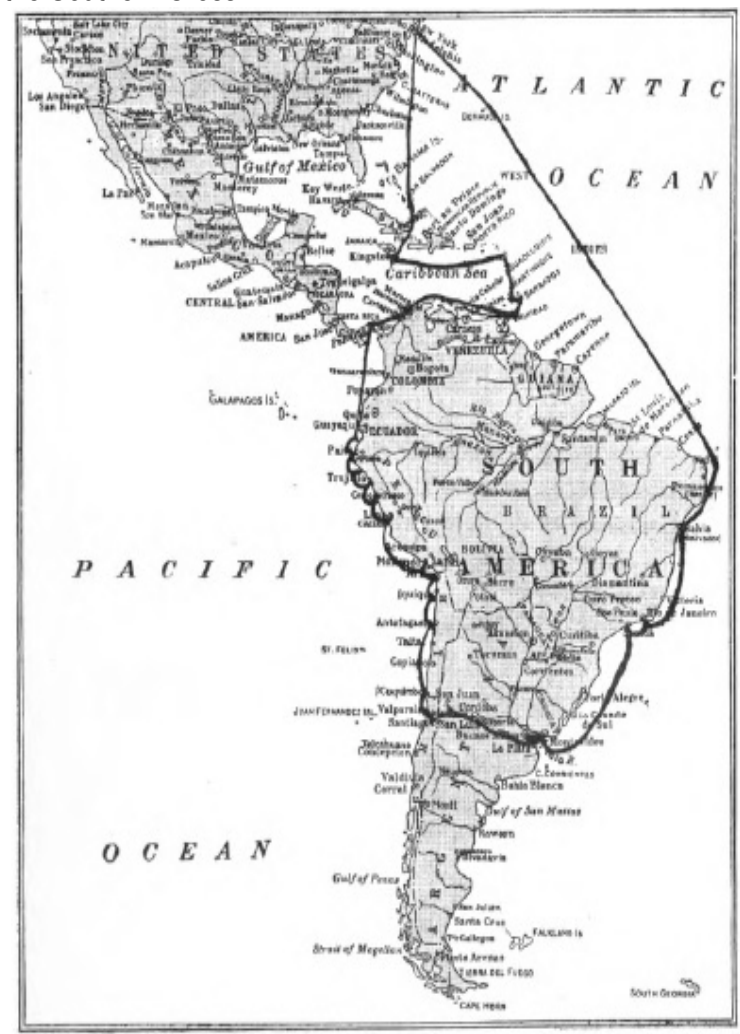

Fonte: Currier (1911).

The Author's Itinerary

O continente era objeto de viagens turísticas organizadas por companhias como a Thomas Cook and Sons e as empresas de vapores HamburgAmerika, Royal Mail Steam Packet Company e Pacific Steam Navigation Company. Já então a América do Sul era indicada àqueles que buscavam caminhos "off the beaten track", e percebem-se indícios da tentativa em diferenciar viajantes e turistas. É interessante observar como o continente é apresentado pelo Reverendo Currier em seu guia de 1911:

A América do Sul, tão longe, é um campo inexplorado pelo turista comum; na verdade contém pouco para atraí-lo. O turista comum segue a multidão; ele viaja pelos circuitos habituais, e caminho de menor resistência. Ele contrata a passagem em um transatlântico da moda, e faz Europa e o 'Oriente' (CURRIER, 1911, p. 15).

Ao estudar esses guias, testemunhos do arranjo do sistema turístico de sua época, depreende-se que Porto Alegre já existe no quadro turístico mundial, embora se encontre como desvio de rota em um continente periférico aos grandes fluxos internacionais e caro de se visitar. À mesma época, em 1915 (GOIDANICH, 1992), ao reverso dessa situação, instala-se em Porto Alegre a Exprinter, agência de viagens e casa de câmbio vinculada ao Banco Superville com matriz em Buenos Aires, permitindo à burguesia local a possibilidade de 'conhecer o mundo' engajando-se em um tour. Ou seja, a capital gaúcha vinculava-se ao sistema turismo global também - e talvez predominantemente - na condição de núcleo emissor. A cidade adquire a função de centro distribuidor dos fluxos turísticos na região, como atesta o Catálogo da Exposição Farroupilha de 1935, vetor de expansão do Turismo e sua urbanização para outras regiões do Estado em práticas como o veraneio à beira-mar no Litoral Norte, a busca do refrigério na Serra Gaúcha.

O Catálogo da Exposição de 1935 foi o primeiro texto encontrado dirigido a turistas escrito por portoalegrenses. Nesta publicação comemorativa, o que é descrito como de interesse para os visitantes são as transformações urbanas promovidas pelo governo de inspiração positivista do intendente Otávio Rocha. 0 título da apresentação é "Porto Alegre, cidade que se renova" (RIO GRANDE DO SUL, 1935, p. 29), ali são elencados feitos como as grandes avenidas, os novos prédios públicos, os jardins de recreação e os trabalhos de saneamento. A cidade buscava mostrar aos visitantes sua conformidade com os signos da modernidade. Ao apresentar 0 espetáculo da modernidade e as formas de sociabilidade burguesas, Porto Alegre reproduz regionalmente, para a população de sua área de influência, o caminho indicado por Duhamel (2007a) no movimento de turistificação das metrópoles globais em que o interesse turístico estava assentado na possibilidade de estar em copresença com a modernidade e com o patrimônio histórico. Isso significava também 0 contato com eventos que apresentavam as vanguardas, tais como as exposições 
universais que 0 evento busca reproduzir. Assim, o discurso da cidade moderna, progressista, higienizada é 0 tom das primeiras publicações voltadas para os visitantes, tais como o catálogo da Exposição do Centenário Farroupilha em 1935, e das comemorações do bicentenário da cidade, em 1940.

Ao analisar a publicação de 1935 encontra-se uma interessante diferença entre 0 termo touriste, escrito originalmente em francês, e os outros visitantes 'riograndenses', indicando talvez o modo como a noção desse substantivo foi construída e preenchida de sentido por ali. Aos primeiros, é assinalada a função de "atestar o progresso da cidade". Aos locais, visitar a exposição é tido como "dever cívico imprescriptivel" (RIO GRANDE DO SUL, 1935, p. 11).

Ao se analisar os catálogos contemporâneos promovidos pelo órgão municipal de Turismo nota-se que ainda hoje existe certa confusão entre a figura do turista e do investidor, ou pessoa de negócios. Parece haver ainda uma distinção entre a hospitalidade oferecida aos visitantes internacionais ocidentais e àqueles locais, ou sul-americanos.

O catálogo ainda dá pistas a respeito da organização do Turismo de então. A exposição viu o início de uma iniciativa dedicada à função de acolher visitantes e que lhes apresentava a cidade em um escritório de informações turísticas (GOIDANICH, 1992). Os meios de hospedagem dispunham de agentes para ofertar e conduzir os turistas desde os dois portos fluviais ou da estação férrea até seus estabelecimentos. Esses meios de acesso à cidade hoje não existem mais, e os canais de distribuição da oferta hoteleira são outros. Outra diferença daquele arranjo comparado a hoje é a questão escala a partir da qual era percebida a presença de visitantes. Embora poucos numerosos para os padrões contemporâneos, esses forasteiros influenciavam a dinâmica do local ao torná-lo objeto de uma intencionalidade turística.

Além da cidade, apresentada sempre como moderna e cosmopolita, outros cenários para práticas turísticas existem em Porto Alegre. O próprio Rio Guaíba adquire novos usos, com as práticas balneárias e também desportivas, vide os clubes de remo ou natação, muitos de origem germânica ${ }^{2}$ como a Sogipa, Grêmio Porto Alegrense, Grêmio Náutico União, para citar alguns. Um exemplo desse impulso é a subversão turística do 'trenzinho da Tristeza'. Implantado ainda no século XIX ligando o centro à Ponta do Asseio, tinha

\footnotetext{
2 Uma agenda de pesquisas futuras é rastrear esse movimento de importação de práticas turísticas cuja surgimento foi alhures e analisar sua importação para o Brasil, ou verificar o caso de invenções autóctones. Uma hipótese prematura é que a imigração européia no sul poderia implicar uma origem distinta do sudeste em que a importação se deu através da elite cafeeira. As implicações dessa possivel distinção também restam a ser investigados.
}

por finalidade afastar os dejetos do núcleo urbano, mas tornou-se o transporte de banhistas rumo aos, agora, balneários de Pedra Redonda e Ipanema. Posteriormente, essas áreas de balneários foram incorporadas ao cotidiano da cidade, perdendo, ou ao menos atenuando fortemente, seu caráter turístico, para o que contribuiu também a poluição das águas, além da ampliação de conexões com outros locais mais adequados aos gostos dos veranistas contemporâneos, tais como as praias marítimas.

\subsection{2 "Porto Alegre: cidade de Turismo", Guia do Touring Club 1955}

Vinte anos depois, a literatura turística sobre Porto Alegre testemunha outro arranjo em "Porto Alegre: cidade de Turismo", publicado inicialmente no almanaque de Pimentel (1945, p. 592) "Aspectos Gerais de Porto Alegre" e ampliado no guia do Touring Club de 1955 (p.6), cuja edição foi coordenada por Goidanich. Porto Alegre é descrita como uma moderna cidade industrial, com arranha-céus e entorno pitoresco. Cabe apontar que até a década de 1960 Porto Alegre se concentra no centro, cuja verticalização, datada dessa época, é testemunho.

O guia produzido pelo Touring Club local (1955) apresenta uma cidade cuja identidade se assenta no progresso e em sua modernidade, atestados por sua importância enquanto capital e centro industrial. Além de uma apresentação da Geografia urbana de Porto Alegre em 'Retrato da cidade a 'vol d'oiseau' (TOURING CLUB, 1955, p. 18), aponta-se o que deveria chamar a atenção dos visitantes: as zonas de comércios e grandes magazines, a diversão noturna e oferta cultural, a arquitetura e trabalhos de modernização.

É neste cenário urbano verticalizado que é possivel testemunhar efervescência cultural da cidade, em palcos como a Rua da Praia e a área da cinelândia, nos arredores da atual Praça da Alfândega. Hoje, essa área ainda tem um peso importante no discurso turístico sobre Porto Alegre, no entanto, é notável sua mudança após o processo de descentralização e mudança da fisionomia urbana por influência do automóvel ${ }^{3}$.

Apesar de abrigar instituições culturais, a Praça da Alfândega é atualmente caracterizada como um núcleo que concentra instituições do setor financeiro e bancário e que perdeu o status de vitrine da cidade, ao

\footnotetext{
3 Pesavento apresenta essa mudança "[...]os shopping centers que possibilitaram às camadas médias urbanas e às classes abastadas a participação num mercado de consumo sofisticado, em ambientes protegidos da marginalidade, cada vez mais presente na área central de Porto Alegre. [...] A Praça da Alfândega, Praça XV e a Praça Dom Feliciano, de lugares da sociabilidade burguesa transformaram-se em lugares de prostituição, de desempregados e biscateiros." (PESAVENTO, 1999, p. 165).
} 
deixar de ser seu principal portão de entrada com a superação do transporte via fluvial.

No Guia do Touring Club (1955) existe ainda a proposta de dois circuitos turísticos em automóvel pelos arrabaldes da cidade, um em direção às colinas da zona leste e outro às praias do Guaíba. Ambos reproduzidos nas figuras 5 e 6 , respectivamente.

Figura 5. Reprodução do Percurso A proposto pelo Touring Club (1955).

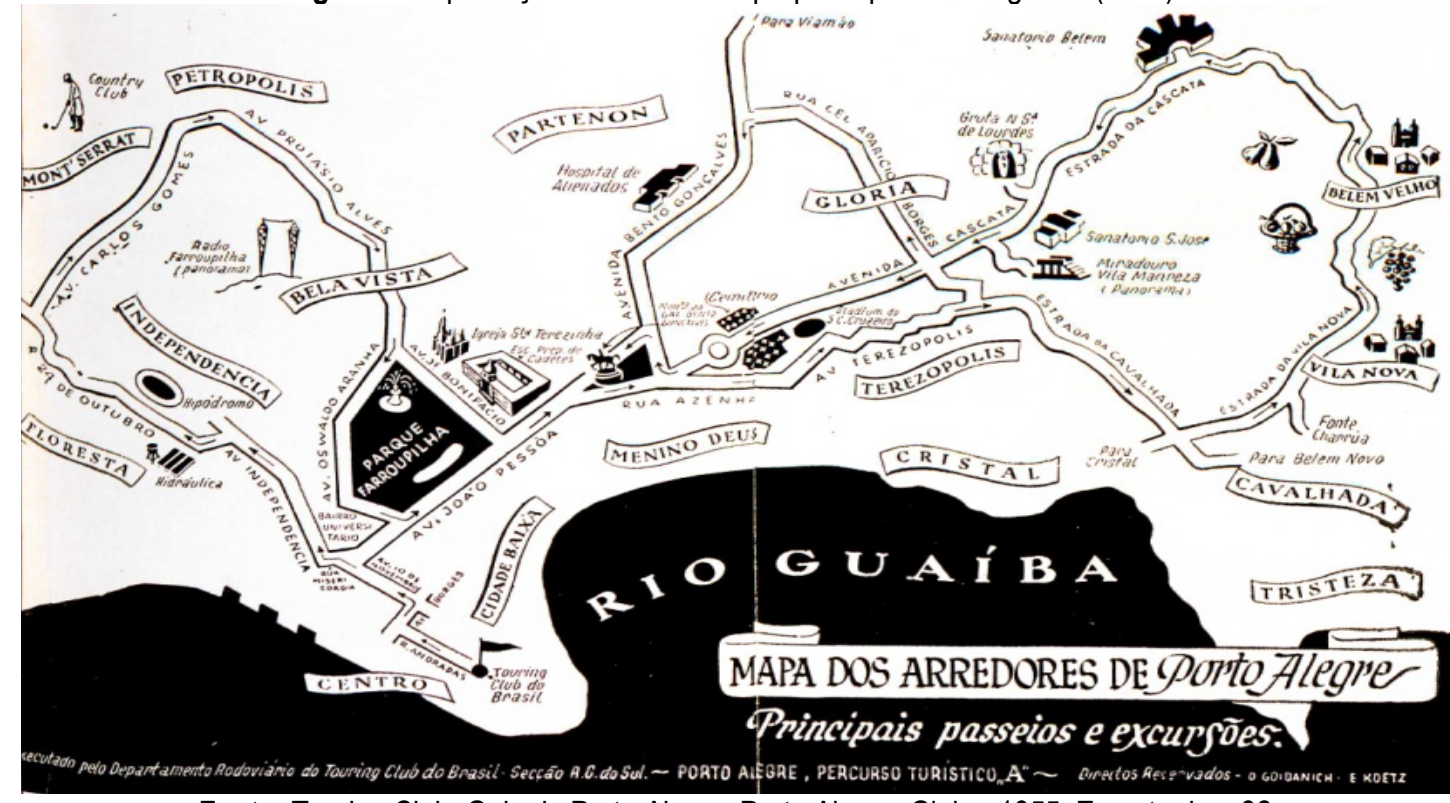

Fonte: Touring Club. Guia de Porto Alegre. Porto Alegre: Globo, 1955. Encarte da p.32

Figura 6. Reprodução do percurso B proposto pelo Touring Club (1955).

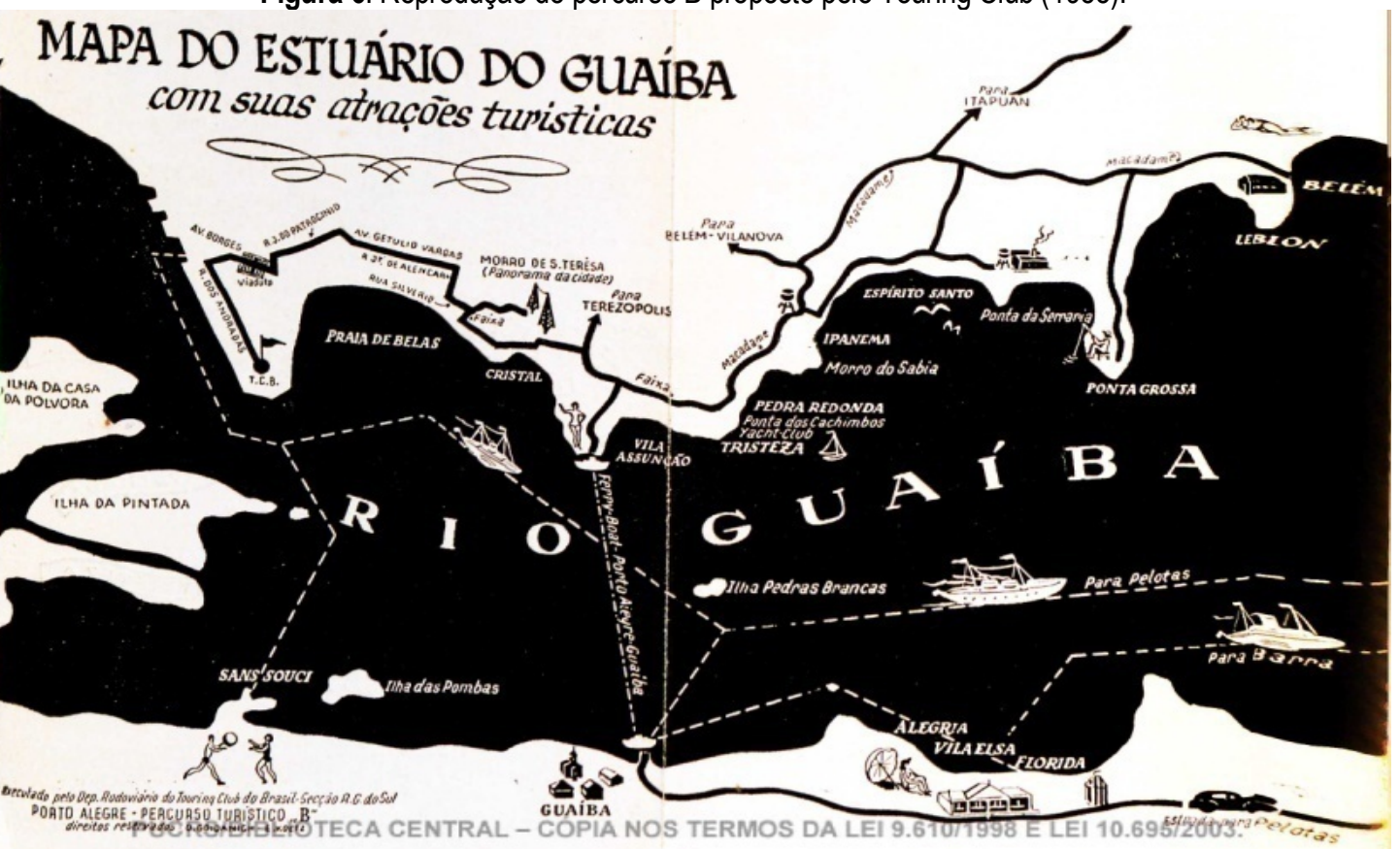

Fonte: Touring Club. Guia de Porto Alegre. Porto Alegre: Globo, 1955. Encarte da p.32.

Essas iniciativas de turistificação, assim como a compilação dos dados da oferta turística, a produção de uma cartografia dedicada a esse fim e a manutenção de um escritório de orientação e informações aos visitantes são conduzidos por uma associação privada: o Touring Club. É uma instituição que nasce para incentivar o uso do automóvel. Aí sua atuação na produção de mapas rodoviários e na sinalização viária, mas também na formação de motoristas, na busca por compatibilização legal entre as habilitações de condutores de diferentes Estados, na oferta de assistência mecânica, na promoção de 
eventos automobilísticos, entre outras iniciativas. Sua existência se deve em parte à influência dos Touring Clubs dos países vizinhos, Argentina e Uruguai, onde a promoção de uma cultura turística como instrumento para integração nacional, valorização patrimonial e promoção do lazer parece ter sido mais forte que no Brasil. Todos os clubes, por sua vez, estavam federados à uma associação internacional com sede na Suíça (GOIDANICH, 1992). Assim, um sócio do Touring Club Porto Alegre poderia ser atendido por outras instituições congêneres desta rede global. Recorda-se, mais uma vez a importação, ou migração de práticas, imaginários e cristalizações vinculados ao turismo.

Um aspecto marcante nos trabalhos do Touring Club é o entendimento que o desenvolvimento do Turismo regional (GOIDANICH, 1992) é tido sinônimo de ações como: sinalização, traçado de roteiros, pontos de apoio para informação, elaboração de guias. Isto é, está centrada sobre o provimento de repertório e marcadores que habilitem uma intencionalidade turística sobre o espaço. Algo tão necessário quanto básico, mas que, no entanto, parece pouco presente da agenda da LT atual pautada na ideia de segmentação de público, muitas vezes desvinculada do território apresentado.

Lendo a publicação sessenta anos após sua impressão, não podemos deixar de perceber o quanto alguns elementos tidos como expressão de uma cidade que se modernizava, e por isso dignos de nota, hoje integraram-se no cotidiano, perdendo seu brilho; isso quando não sofreram certa obsolescência. Os exemplos são múltiplos.

O Guia de 1935 destacava a modernidade do novo Palácio do Governo de 1921, as publicações atuais 0 apresentam como patrimônio histórico vinculado ao passado da administração positivista da cidade. Nos anos 1950 destacava-se a canalização do arroio Dilúvio, obra de engenharia considerável inaugurada àquela época e que hoje é uma paisagem banal, um riacho urbano poluído. Outro caso é o mirante de Santa Teresa, destaque nos anos 1950 e 1970 pelo panorama que de lá é possível apreciar, hoje significado pela insegurança (COSTA, 2015) ${ }^{4}$ visto que foi objeto de urbanização irregular. Esses exemplos ressaltam o caráter situado e contingente do turismo.

A função turística dos espaços compete com outros usos e interesses no território. Em alguns casos essa pode ser preterida, em outros estimulada. Por outro lado, como aponta Violier (2008) o status

\footnotetext{
${ }^{4}$ Assim é chamada da reportagem que descreve a situação atual do lugar: "Assaltos, tiroteios, disputas de gangues e extorsões tiram a tranquilidade de moradores e comerciantes local que já foi ponto turístico e cartão-postal e hoje está dominada pelo tráfico".
}

turístico se constrói a partir do jogo dos visitantes com a alteridade. Se a especificidade desse caráter particular a um local turístico torna-se comum ou não é objeto de manutenção, o próprio status turístico do local se erode. É o caso de alguns centros culturais, muito comentados em sua inauguração e depois objeto de uma triste obsolescência.

Ainda há o caso da mudança dos cânones que enquadram o que é percebido como merecedor de atenção, nos anos 1950 havia um destaque para uma imagem urbana vinculada a indústria, sinônimo de progresso, hoje os valores que conotam a urbanidade são outros como a festa e o cosmopolitismo. Ainda sobre os cânones turísticos é curioso notar que há um destaque seletivo da LT para arquitetura da cidade, com ênfase para o ecletismo do início do século XX e a invisibilidade do Modernismo dos 1950 e 1960.

\subsubsection{Turismo como função do poder público, Embratur e Epatur nos anos 1970}

Há um contraste interessante entre os guias de 1955 e da década de 1970. Enquanto o primeiro é produto do terceiro setor, os outros atestam explicitamente que o Estado teria um papel a cumprir frente ao Turismo. As publicações da então Empresa Brasileira de Turismo (EMBRATUR, 1978), 'Guia do Rio Grande do Sul' e da Empresa Porto Alegrense de Turismo (PORTO ALEGRE, 1977), 'Porto Alegre: terra de gente" apresentam o Turismo como objeto de uma política estatal.

\section{Lê-se no prefácio da primeira publicação:}

[...] Antes, a idéia de Turismo limitava-se a um símbolo conspícuo de classe, ia pouco além do lazer e do divertimento de alguns, num mundo espaçoso e, por infinitas razões, mais simples.

$\mathrm{Na}$ atualidade, o Turismo tem considerável importância social, política e econômica, pois, democratizando-se, transformou-se em instrumento de aproximação dos povos e meio de divulgação cultural.

Entretanto, esse instrumento carrega consigo riscos e ameaças à identidade das culturas nacionais, que precisam contar com mecanismos de defesa, preservação e promoção de seus valores culturais e de sua herança histórica.

No Brasil, essa tarefa é dever do Estado, não limitada à expressão física e territorial, mas abrangente, incluindo todos os valores que constituem a alma nacional: seu patrimônio histórico, artístico e cultural [...] (EMBRATUR, 1978,p. VIII) 
É um contexto de fortalecimento do estado nacional, conduzido pelo governo autoritário dos militares, que buscava com o Turismo a promoção: de um orgulho nacional, da imagem de um país alegre $e$ harmonioso, do crescimento econômico, bem como a desconcentração do desenvolvimento. A missão de conduzir esse processo é vista como pertencente ao setor público, à diferença do momento anterior. Há uma articulação entre as esferas de governo, a publicação, patrocinada pelo governo federal na figura da Embratur e Ministério da Indústria e Comércio:

[...] contou com a colaboração de uma equipe de especialistas, está baseado em elementos colhidos em fontes oficiais, particularmente, na Companhia Rio-Grandense de Turismo - CRTUR, órgão executivo do Sistema Estadual de Turismo, e na Empresa Portoalengrese de Turismo S.A. - EPATUR, órgão executivo da política de Turismo da Prefeitura Municipal de Porto Alegre, que permitiram o acesso a seus atualizados levantamentos no setor. (EMBRATUR 1978, p.1).

Ao tornar-se um programa de Estado, passam a ser funções públicas: estabelecer roteiros e itinerários turísticos, informar visitantes e manter atualizados bancos de dados oficiais sobre o setor. Além dessa atuação, desenvolver o Turismo implica em ações de maior peso, tais como: financiar e estabelecer linhas de crédito para empreendimentos hoteleiros; desapropriar terrenos para criação de parques turísticos; coordenar campanhas publicitárias e realizar a promoção turística dos destinos; fiscalizar empresas turísticas e realizar estudos técnicos que orientem a política de desenvolvimento coordenada pelo Estado. No começo da década de 1970, a partir da Superintendência do Desenvolvimento da Região Sul (SUDESUL), foi contratada uma consultoria espanhola Tecnibéria-Engevix, que realizou um extenso levantamento e indicações para Planos de Turismo dos três estados da região sul.

Em escala local, a Empresa Pública de Turismo de Porto Alegre (EPATUR), tinha por finalidade a organização de eventos de interesse turístico, a manutenção de uma estrutura de acolhimento aos visitantes, o planejamento e promoção da oferta turística da cidade.

Como imagem promovida da cidade, a modernidade e o progresso dão espaço à história e à tradição. Nota-se a valorização do passado e do regionalismo, presente nos Centros de tradições Gaúchas (CTGs), na decoração temática dos postos de informação turística - denominado bolicho - e também em uma fazendola criada na Estância da Harmonia, um parque junto ao centro da cidade, onde os turistas poderiam montar a cavalo, ver aspectos folclóricos, testemunhar provas de laço entre outras habilidades do Gaúcho.

$\mathrm{Na}$ época da ditadura civil-militar Porto Alegre passou por grandes transformações: com obras viárias pautadas pelo preceito de difusão da cidade que priorizou à circulação baseada no automóvel; com a construção de novos prédios públicos fora do centro, expressando a modernidade e o crescimento do país; com a remoção da população pobre para áreas afastadas da cidade. É em meio a esse movimento de expansão da cidade e de grande transformação da paisagem urbana que surgiram as primeiras iniciativas de preservação do patrimônio edificado da cidade. Um exemplo emblemático é o Mercado Público, protegido por reivindicação popular após ser ameaçado para dar lugar à construção de uma avenida, em 1979. No guia de 1955 o Mercado estava "condenado a desaparecer" (p.24), já em um folheto de 2007 é visto como "uma síntese da cidade, sua história e sua diversidade" (PORTO ALEGRE, 2007, p.13).

Os guias de 1970 também testemunham o processo de descentralização de uma cidade que está se tornando polinuclear e desindustrializando-se. À verticalização do centro seguiu-se a perda de algumas de suas funções para outras áreas da cidade e a dispersão do contingente da população residente para outros bairros. $O$ abandono do centro pelas altas classes a partir dessa época é também tendência em outras cidades brasileiras, como aponta Villaça (2001).

Neste movimento, a localização do escritório de informações turísticas, por exemplo, é uma tentativa de refuncionalização da antiga estação de bondes, que foram substituídos pelos ônibus. Outro caso é conversão da rua principal do centro da cidade em zona peatonal, em busca de um aspecto mais 'humano' e da valorização do comércio, em um bairro que se densificou de modo acentuado, onde a mobilidade individual em automóvel colocava problemas. Outra inovação constatada é a emergência turística de museus de arte e equipamentos culturais, antes inexistentes.

\subsubsection{Abertura econômica e Administração Popular (1989-2004)}

A década de 1980 é marcada por uma lacuna no corpus de literatura turística examinado. Em busca no arquivo municipal, notou-se que em geral os documentos relativos à EPATUR estavam restritos à organização do Carnaval. É apenas nos anos 1990 que emergem novamente iniciativas de roteirização. Certamente Porto Alegre não deixou de ser visitada, como atestam os dois mapas 
encontrados, mas talvez isso indique a menor importância conferida ao turismo na agenda de desenvolvimento da cidade. Oscilação que não deixa de recordar o caráter contingente do sistema turismo.

Ao analisar a economia de Porto Alegre no final da década de 1980, Alonso e Bandeira (1988) constatam que ocorreu:

[...] uma modificação na estrutura da economia de Porto Alegre, paralela a uma redefinição de suas relações, na condição de metrópole, com a economia do resto do Estado e, de forma particular, com a das áreas mais próximas da Capital, como as Regiões Metropolitana e Perimetropolitana. (ALONSO e BANDEIRA, 1988, p. 7).

As atividades terciárias substituíram a indústria como matriz produtiva do município. Esse é um processo multifatorial e complexo que não cumpre aqui examinar. Porto Alegre cresce, portanto, como pólo de serviços e centro de comando terciário da economia regional. É neste contexto de inserção em uma nova arquitetura produtiva marcada pela abertura econômica e importância das tecnologias de informação e comunicação que devem ser vistas as iniciativas de ativação turística de Porto Alegre retomadas após certa letargia dos anos 1980.

Em Porto Alegre, o período entre 1989 e 2004 foi marcado pela Administração Popular. A cidade foi uma espécie de laboratório para as políticas públicas de esquerda, que se tornaram mundialmente conhecidas, como o Orçamento Participativo e o Fórum Social Mundial. Elementos que foram incorporados ao imaginário turístico da cidade e a projetaram como marca global, como atestam as apresentações feitas pelos guias Michelin (2013) e Lonely Planet (2010) sobre a cidade.

Em certo momento o Turismo foi visto como um meio de promoção de uma imagem de cidade, sobretudo para seus próprios habitantes. Neste sentido a proposta de Porto Alegre ecoava aspectos daquela de Barcelona, cujo modelo de gestão urbana inspirou muitas cidades. Na cidade catalã havia a premissa de que "organizar um espaço público em uma lógica de descoberta coletiva é concebê-lo como um instrumento de reapropriação de um espaço urbano por uma comunidade" (CLARIMONT e VLĖS, 2010, p. 16). Em relação ao Turismo existia a concepção de:

No início, neste projeto urbano [de Barcelona], o Turismo não tem um papel central. Os primeiros projetos de planejamento urbano da democracia (1979) vinculam-se menos à valorização da cidade visando ao sucesso do Turismo que a "reconstruir a cidade sobre a cidade" para seus habitantes remediando as carências de equipamentos públicos. Era conveniente então "sanear 0 centro e monumentalizar a periferia" (CLARIMONT e VLĖS, 2010, p. 18).

Em Porto Alegre, trabalhando sobre o conceito de 'Turismo cidadão' (GASTAL e MOESCH, 2007) há uma proposta de desenvolver as comunidades das periferias por meio do Turismo e de fazer com que a população dos bairros centrais conhecesse e valorizasse sua cidade, destinando um novo olhar sobre seu patrimônio. Nessa época também está em discussão um novo Plano Diretor e nota-se como enunciados na LT reproduzem de algumas metas do documento como: 'Cidade que promove a qualidade de vida e do ambiente'; 'Cidade culturalmente rica e diversificada'; 'Cidade atrativa e competitiva'. Cumpre recordar que nesse momento de abertura econômica do país é à instância local que cabe um papel mais ativo na interação com atores globais, visando a um melhor posicionamento nessa reestruturação da arquitetura produtiva capitalista (HARVEY, 2005; SPIROU, 2011; SELBY, 2004; DE MATTOS, 2006). A busca por atrair investimentos, a formação de uma city brand, as iniciativas de empresariamento urbano fazem parte de contexto com 0 qual essa administração busca dialogar. Esses elementos tornam mais evidente 0 papel do turismo como vetor de urbanidade, e consequemente mais propícia a sua inserção como pauta da política local e na discussão sobre o projeto de cidade.

Houve esforços na turistificação do Centro, com itinerários guiados oferecidos gratuitamente pela prefeitura; a refuncionalização de edifícios patrimonializados em centros culturais (Usina do Gasômetro, Casa de Cultura Mario Quintana, Santander Cultural, Memorial do Rio Grande do Sul, Museu de Artes do Rio Grande do Sul); a reforma do Mercado Público, em 1997, e do Theatro São Pedro. Vê-se também a emergência da noção de segmentação turística, até então inexistente. Definem-se a Alfândega, Matriz e Mercado como polos histórico-culturais. Políticas das quais o Guia Turístico de 2003 é um bom testemunho (PORTO ALEGRE, 2003).

Além dos bairros centrais, a expansão de iniciativas turísticas estendeu-se para zonas periféricas da cidade, como as ilhas do Delta do Jacuí, os morros da Zona Sul, bairros Lami, Belém Velho e Belém Novo. Houve iniciativas de ativação turística da comunidade de pescadores da llha da Pintada, das pequenas propriedades rurais ainda existentes no extremo sul do território portoalegrense, bem como das associações de catadores 
de resíduos recicláveis e de itinerários ecológicos em parques urbanos e reservas naturais municipais (PORTO ALEGRE, 2000?).

A promoção de dois eventos, a 'Semana de Porto Alegre' e a 'Semana no Turismo', em que todos esses itinerários eram ofertados pela prefeitura dava visibilidade a essa diversidade. Algo que marcou esse período foi a articulação entre as diferentes esferas do poder público municipal. Assim, a constituição de uma imagem turística da cidade também se valia de suas políticas culturais, tais como a descentralização dos espaços culturais, o projeto de história oral que registrou a memória de diferentes bairros, a promoção de festivais teatrais internacionais, e 0 surgimento da Bienal Internacional de Artes do Mercosul. A iniciativa de integração regional entre os países platinos aliás foi uma das marcas através das quais Porto Alegre buscou se constituir, como evidencia o texto "Assumindo a condição de capital do Mercosul" (PORTO ALEGRE, 1993-1996?, s.p.).

De fato, a proximidade com o Prata ainda rende à cidade a condição de terceiro principal portão de ingresso de estrangeiros no Brasil. Há uma busca por promover políticas de circulação cultural que fossem alternativas, e contornassem, à excessiva polarização exercida pelo eixo Rio / São Paulo. Um exemplo que atesta essa ênfase no Mercosul foi a edição de eventos "Porto Alegre em Buenos Aires", "Buenos Aires em Porto Alegre" (GERHMANN, 1998).

No plano administrativo há uma série de mudanças, expressas na Lei Complementar 477 de 2000, que dispõe sobre a Política Municipal de Turismo (PORTO ALEGRE, 2000). A EPATUR foi extinta, depois de denúncias de corrupção sobre 0 mau uso de seus mecanismos administrativos. A política municipal de Turismo, produto de conferências e debates, foi conduzida por um Escritório da Secretaria de Indústria e Comércio (SMIC), sob a supervisão de um Conselho de Turismo (CONTUR) composto por diferentes entidades do setor, tais como associações hoteleiras, comerciais, de agentes de viagens, artesãos, etc. Foi criado também um Fundo Turismo (FunTurismo) para sustentar financeiramente essas iniciativas, com aportes de capital do poder público e da iniciativa privada. É interessante recordar que nesse período também na esfera federal há uma proposta de descentralização das políticas de turismo, expressa no Plano Nacional de Municipalização do Turismo.

No entanto, ressalta-se que iniciativas importantes vieram do setor privado. Notadamente, a criação do Porto Alegre Convention \& Visitors
Bureau, cujo principal objetivo é a captação de eventos para cidade. A ampliação da oferta de equipamentos como os centros de convenções da Federação das Indústrias (FIERGS) e da Pontifícia Universidade Católica (PUCRS), que também inaugurou um Museu de Ciências e Tecnologia totalmente interativo.

Os rastros de turistificação presentes na literatura turística de Porto Alegre estão, muitas vezes, vinculados aos eventos que a cidade sedia. São nessas ocasiões em que parece haver uma preocupação em apresentá-la aos seus visitantes. São como molas propulsoras, catalisadores. Alguns exemplos, a publicação de 1990 "Porto Alegre capital nacional do Turismo" (PORTO ALEGRE, 1990?, s.p.) ao sediar o encontro da ABAV (Associação Brasileira dos Agente de Viagem). 0 encontro da rede Mercocidades de Turismo, cuja marca estava em materiais datados do ano de 2000 (PORTO ALEGRE, 2000). Além da grande prova do Turismo em Porto Alegre nesse período: a organização do Fórum Social Mundial (FSM). Promovido em sua primeira edição em janeiro de 2001, durante o tradicional período estival de baixa ocupação hoteleira, sua maior edição foi a de 2005 que levou 150 mil pessoas à cidade, segundo os organizadores. Além de 'colocar Porto Alegre no mapa', como atesta o Guia Michelin (2013), e atrair a atenção da mídia internacional, o evento foi uma ocasião de apresentar um novo olhar sobre Porto Alegre e que tornou sua visita mais fácil: o Linha Turismo. Embora cidades como Curitiba já apresentassem iniciativas similares com Jardineiras, esse foi 0 primeiro ônibus de dois andares (doubledecker) turístico a operar no país, e foi adquirido através das demandas do Orçamento Participativo. Percebe-se que o FSM foi a ocasião de sistematização de numerosas iniciativas de ativação turística cujas rastros estão presentes em guias e folhetos traduzidos em cinco idiomas, expressando a proposta de internacionalização dessa oferta

Em 2005, mesmo ano da maior edição do FSM, houve uma mudança de orientação no governo da prefeitura e o abandono dessa imagem de cidade muito ligada à administração anterior, que ficara 16 anos no poder. A pasta de turismo torna-se uma Secretaria, mas não há mais uma proposta declarada de política compartilhada entre os diferentes atores do executivo. Nota-se, portanto, uma ruptura em relação a esse período, 0 que ensejaria uma nova fase. Não é a proposta, no entanto, aprofundarmos a análise contemporânea do turismo na cidade, apenas ressaltar seu caráter processual e que segue em transformação. 


\subsection{Síntese: o caráter histórico da articulação de Porto Alegre ao Sistema Turismo}

Evidencia-se o caráter histórico e situado do desenvolvimento da função turismo em Porto Alegre em um processo marcado por avanços, retrocessos e intermitências. Não obstante, existe uma cronologia que não pode ser invertida e que aponta os parâmetros a partir dos quais é possível se estabelecer os critérios do que era entendido como Turismo em cada época e qual a posição da cidade neste sistema.

Ao compreender o turismo enquanto invenção, o primeiro aspecto percebido é o enquadramento da paisagem da cidade nos cânones estéticos do turismo a partir de outras práticas de visitação, de interesse científico. É o caso da caça por panoramas e atribuição de adjetivos como pitoresco. Há ainda a integração da cidade à periferia do Sistema Turismo, movimento possibilitado pelas transportadoras internacionais e instituições financeiras.

Destaca-se também a produção de um megaevento, a Exposição do Centenário Farroupilha, oportunidade em que surge pela primeira vez uma estrutura receptiva voltada para visitantes designados como touristes. Porto Alegre ao olhar destes deveria ser percebida como moderna e progressista. Há uma promoção da visita à cidade como compromisso cívico nos anos 1930, e a diferenciação entre touristes e visitantes regionais. Entre os anos 1940 e 1960 notamos a promoção Turismo como estímulo e resultado do rodoviarismo. Iniciativas como a sinalização rodoviária e a produção e sistematização de informações para os turistas são novidades.

Nos anos 1970 está o entendimento de que o Estado deveria exercer uma protagonismo no estímulo à atividade. Esta época também vê surgir um interesse pelo folclore e patrimônio local, dada à radicalidade das transformações pelas quais a cidade passou ao priorizar o automóvel e assim descentralizar-se adotando um modelo pluricentral.

Nos anos 1990 e início dos 2000, o turismo é subterfúgio na busca por inserção em um cenário globalizado da abertura econômica e tendências como a refuncionalização de prédios históricos em equipamentos culturais, bem como a busca por estabelecer uma city brand. Nos 2010 segue uma ênfase na individualidade, marcada por propostas de segmentação da oferta turística.

Essas variações convivem com algumas permanências, como 0 apreço ao contato com a modernidade - do trânsito acelerado à rede wi-fi - e a estratégia pautada na promoção de eventos - da exposição de 1935 à Copa de 2014. Os eventos parecem ter importância fundamental no processo de turistificação de Porto Alegre, ao cumprir um papel de articular diferentes atores em prol de um objetivo comum de apresentar a cidade para os visitantes. A Exposição de 1935, o Bicentenário de 1940, o Fórum da ABAV em 1990, o Fórum Social Mundial 2001, 2002, 2003 e 2005, o Mundial de Atletismo Master em 2013, a Copa do Mundo em 2014. Seguindo outra escala e ritmo estão a Semana do Turismo e a Semana de Porto Alegre, o Acampamento Farroupilha, mas que também demonstram a centralidade desse gênero de processo.

\section{CONSIDERAÇÕES FINAIS}

A proposta deste estudo foi a de analisar uma história do turismo em Porto Alegre, mas também de a partir do caso de Porto Alegre verificar tendências gerais do desenvolvimento do próprio turismo. Neste sentido, uma contribuição deste estudo foi considerar - Sistema Turismo não a partir de uma matriz estrutural, mas enquanto uma auto-eco-organização, de extensão global, capaz de adaptar-se e evoluir para garantir seu equilíbrio e sobrevivência.

Ao considerá-lo assim, destaca-se que esta unidade não é uniforme, mas é espacialmente diferenciada. O turismo se constitui de modo distinto e traz implicações distintas para os locais que articula. Ao estudar a parte, Porto Alegre, nota-se 0 quanto a posição da cidade afirma-se em uma rede de interações e mobilidades contemporâneas constituída historicamente.

Em outro sentido, as iniciativas locais para inserir-se neste sistema se assentam e reproduzem expectativas e entendimentos do que é mais adequado como política de turistificação em cada época. A função turismo articula-se neste subespaço e apresenta variações frente à diversidade de impulsos urbanizadores com suas distintas concepções de cidade e formas materializadas na paisagem porto-alegrense. Ela apresenta aqui um caráter periférico e subordinado a outros elementos e funções mais centrais à dinâmica da cidade, o que não é privilégio de Porto Alegre, mas comum em cidades multifuncionais em que o turismo compete com outras funções (VIOLIER e ZARATE, 2007).

Ao identificar Porto Alegre como reprodutora regional de tendências contemporâneas do que é denominado por Turismo Urbano, destaca-se a necessidade de refletir-se sobre o modo como essas orientações gerais, em conjunto com as teorias que delas advêm, são traduzidas e implantadas localmente.

No caso da capital gaúcha evidencia-se um processo semelhante ao relatado pela literatura 
contemporânea sobre Turismo Urbano. Isto é, há um processo de desindustrialização a partir do final do século XX e especialização do núcleo metropolitano no setor terciário. Existem iniciativas de reconversão de alguns espaços centrais em áreas voltadas à cultura - o que inicia nos anos 1970 e se acentua no decênio de 1995 e 2005.

Parece ser justamente em uma administração que se autodenomina popular em que há uma adesão ao ideário do empresariamento urbano, e a proposta de uma city brand - 'Capital do Mercosul' e posteriormente cidade sede do Fórum Social Mundial e do Orçamento Participativo (OP) - para inserir-se na competição pela atração de visitantes e investimentos. 0 exame do processo dessas iniciativas e projetos tendo em vista o turismo, bem como a avaliação de seus sucessos e insuficiências é um campo aberto para pesquisas futuras.

Destaca-se, por outro lado, a obsolescência de muitos investimentos e reformas em edifícios históricos realizadas a essa época, bem como 0 esvaziamento da própria atmosfera política que dava sentido ao FSM e OP como ativos turísticos.

Pontua-se, assim, que a função turística deve compreendida em sua interação, de cooperação ou competição, com outras dinâmicas, usos e interesses existentes em um território, destacando o caráter instável, situado e contingente de seus arranjos. A essa análise interna, deve haver o complemento de uma análise externa, da posição e situação de um destino frente ao conjunto do Sistema Turismo.

Em termos metodológicos, a designação da Literatura Turística como tipo discursivo aponta para a riqueza de um conjunto de documentos. Particularmente, destacamos os folhetos e catálogos que apesar de serem testemunho e reflexo das iniciativas de turistificação nos destinos, não são de uso frequente como fonte de pesquisa. Em uma área em que a documentação é rara, este tipo de fonte traz um potencial interessante para compreensão e estudo das iniciativas vinculadas ao Turismo e merece atenção no campo teórico-metodológico.

Embora o corpus analisado tenha se provado rico e pertinente aos propósitos desta pesquisa, ela poderia ser aliada a outras metodologias. 0 material poderia ter sito utilizado, por exemplo, como ponto de estímulo a relatos de história oral, ampliando de maneira substantiva o entendimento aqui proposto. A principal limitação deste trabalho, no entanto, consiste no fato de ser um estudo de caso, sendo oportunas novas investigações sobre destinos de características semelhantes afim de se traçar paralelos, buscar particularidades e identificar possíveis generalizações.

\section{REFERÊNCIAS}

ABRIL. Guia Quatro Rodas. São Paulo, 1965.

ALONSO, J. F.; BANDEIRA, P. S. A "desindustrialização" de Porto Alegre: causas e perspectivas. Ensaios FEE, Porto Alegre, v. 9, n. 1, p. 3-28, 1988. Disponível em: http://revistas.fee.tche.br/index.php/ensaios/article/view /1167/1525 Acesso em 12 abr. 2017.

ANTONESCU, A.; STOCK, M. Une méthodologie pour reconstruire la mondialisation du tourisme. Mondes $d u$ Tourisme, v. 9, p. 2-18, 2014. Disponivel em: https://tourisme.revues.org/124 Acesso em 12 abr. 2017.

ANTONESCU, A.; STOCK, M. Reconstructing the globalisation of tourism: A geo-historical perspective. Annals of Tourism Research, v. 45, p. 77-88, 2014a. Disponivel em https://doi.org/10.1016/j.annals.2013.12.001 Acesso em 30 maio 2018.

BENI, M. C. Análise Estrutural do Turismo. 9a. ed. São Paulo: Senac, 2003.

BERQUE, A. Paisagem-Marca, Paisagem-Matriz: Elementos da Problemática para uma Geografia Cultural. In: CORREAA, R. L.; ROZENDAHL, Z. Paisagem, Tempo e Cultura. Rio de Janeiro: EDUERJ, 1998.

BOULLÓN, R. Planificación del Espacio Turístico. México: Trillas, 2006.

BOYER, M. História do Turismo de Massa. Bauru: EDUSC, 2003.

BRASIL. Ministério do Turismo. Categorização dos Municípios Turísticos. Ano referência 2017. Brasília: 2018. Disponivel em: http://dados.turismo.gov.br/categorizacao Acesso em 31 maio 2018.

BUTLER, R. The concept of tourist area cycle of evolution: implications for management of resources. Canadian Geographer, v.24, n.1, 1980

CLARIMONT, S.; VLĖS, V. Espaces publics touristiques urbains et développement durable : principes d'aménagement, usages et tensions. Une analyse à partir du cas de Barcelone (Espagne). Urbia: les cahiers du développement urbain durable, Lausanne, v. 10, p. 11-28, jun 2010. Disponível em: https://www.unil.ch/files/live/sites/ouvdd/files/shared/UR BIA/urbia_10/Clarimont_Vles.pdf Acesso em 15 maio 2017.

COSTA, J. L. Crimes e medo marcam rotina no Morro Santa Tereza, na capital. Zero Hora, Porto Alegre, 19 set. $2015 . \quad$ Disponível em: http://zh.clicrbs.com.br/rs/noticias/noticia/2015/09/crime s-e-medo-marcam-rotina-no-morro-santa-tereza-nacapital-4851307.html Acesso em 15 jun. 2017.

CURRIER, C. W. Lands of the Southern Cross. Washington D.C.: Spanish American Publication Society, 1911.

CUVELIER, P. Anciennes et nouvelles formes de tourisme: une approche socio-économique. Paris: Harmattan, 2010.

DE MATTOS, C. Modernización capitalista y transformación metropolitana em América Latina: cinco tendências constitutivas. In: GERAIGES; ARROYO; SILVEIRA 
América Latina: cidade campo e turismo. Buenos Aires/ São Paulo: Clacso, 2006.

DE SOUZA, C. F.; MÜLLER, D. M. Porto Alegre e sua evolução urbana. Porto Alegre: Ed. da UFRGS, 2007.

DUHAMEL, P.Le lieux touristiques. In: STOCK, M. Le Tourisme: acteurs, lieux et enjeux. Paris: Belin, 2003

DUHAMEL, P. Alors, un énième livre sur le « tourisme urbain »? In: DUHAMEL, P.; KNAFOU, R. Mondes urbains du tourisme. Paris: Belin, 2007.

DUHAMEL, P. Patrimoine et modernité: double logique de la production et du renouvellement des villes touristiques. In: DUHAMEL, P.; KNAFOU, R. Mondes Urbain du Tourisme. Paris: Belin, 2007a.

DUHAMEL, P. Le Tourisme: lecture géographique. Paris: La Documentation Française, 2013.

EMBRATUR. ROSENBLATT, M.(Org.). Porto Alegre. Roteiro turístico-cultural de Porto Alegre e cidades vizinhas, Rio Grande do Sul: na terra dos gaúchos. Rio de Janeiro: AGGS, 1978.

ÉQUIPE MIT. Tourismes 2: moments de lieux. Paris: Belin, 2005.

ÉQUIPE MIT. Tourisme 3: révolution durable. Paris: Belin, 2011.

FEE. Tabela 1 - Produto Interno Bruto (PIB) total e per capita, estrutura do Valor Adicionado Bruto (VAB) e população dos municípios do Rio Grande do Sul 2014, 2014. Disponivel em: $<$ http://www.fee.rs.gov.br/indicadores/pibrs/municipal/destaques/>. Acesso em: 10 maio 2017.

FLICK, U. Introdução à pesquisa qualitativa. Porto Alegre: Artmed, 2009.

GASTAL, S.; MOESCH, M. M. Turismo e políticas públicas. São Paulo: Aleph, 2007.

GERHMANN, L. Porto Alegre apresenta sua cultura a Buenos Aires. Folha de São Paulo. Ilustrada, São Paulo, 3 mar. 1998. Disponível em: http://www1.folha.uol.com.br/fsp/ilustrad/fq03039816.ht m Acesso em 04 out. 2017.

GOIDANICH, O. A saga do turismo no Rio Grande do Sul. In: FLORES, H. (Org.). Turismo no RS: 50 anos de pioneirismo no Brasil. Porto Alegre: EdiPUCRS, 1992.

GRAVARI-BARBAS, M. Aménager la ville par la culture et le tourisme. Paris: Groupe Moniteur, 2013.

HARVEY, D. A produção capitalista do espaço. São Paulo: Annablume, 2005.

HAYLLAR, B.; GRIFFIN, T. E. A. Turismo em cidades: espaços urbanos lugares turísticos. Rio de Janeiro: Elsevier, 2011.

HIRST. A Guide to South America. Nova lorque: The Macmillan Company, 1915.

IBGE. Regiões de Influência das Cidades 2007. Rio de Janeiro: IBGE, 2008. Disponivel em: http://biblioteca.ibge.gov.br/visualizacao/livros/liv40677. pdf acesso em 29 maio 2017.

JANSEN-VERBEKE, M. Urban Tourism. In: JAFARI, J. Encyclopedia of Tourism. New York: Routledge, 2009. p. 615-617.

KNAFOU, R. L'urbain et le tourisme : une construction labourieuse. In: DUHAMEL, P.; KNAFOU, R. Mondes Urbain du Tourisme. Paris: Belin, 2007.
LEOTTA, N. Approcci visuali di turismo urbano. Milano: Hoepli, 2005.

LÖFGREN, O. Storie delle vacanze. Milano: Bruno Mondadori, 2006.

LONELY PLANET. LOUIS, R. (COORD.). Porto Alegre.. In: PLANET, L. South America on a sho-estring, big trips on small budgets. 11a. ed. ed. Singapura: Lonely Plane, 2010. p. 302-304.

MAINGUENEAU, D. Discurso e análise de discurso. São Paulo: Parábola, 2015.

MICHELIN. Une vitrine des progrès sociaux. In: MICHELIN Brésil. Le Guide Vert. Paris: Michelin, 2013. p. 308-313.

PESAVENTO, S. Memória Porto Alegre: espaços e vivências. Porto Alegre: Ed. UFRGS, 1999.

PIMENTEL, F. Aspectos Gerais de Porto Alegre. Porto Alegre: [s.n.], 1945.

PIMENTEL, M. R. A sociedade urbana e a espacialidade turística. Turismo \& Sociedade, Curitiba, v. 2, out. 2009. 128-143. Disponível em http://revistas.ufpr.br/turismo/article/view/15832 Acesso em 21 jun. 2017.

PIMENTEL, M. R.; CASTROGIOVANNI, A. C. O Urbano e o Turismo: uma construção de mão dupla. Boletim Gaúcho de Geografia, Porto Alegre, v. 43, n. 2, p. 81105, dez 2016. Disponível em: http://seer.ufrgs.br/index.php/bgg/article/view/58960/40 344 Acesso em: 30 maio 2018.

PORTO ALEGRE. Lei Complementar 477 de 12 de maio de 2000. Porto Alegre: SIREL, 2000. Disponível em : http://www2.portoalegre.rs.gov.br/cgi-bin/nphbrs?s1=000023011.DOCN.\&l=20\&u=\%2Fnetahtm| $\% 2$ Fsirel\%2Fsimples.html\&p=1\&r=1\&f=G\&d=atos\&SECT 1=TEXT. Acesso em 08 ago. 2017.

PORTO ALEGRE.EPATUR S/A.. Porto Alegre pra Turista ver Capital Nacional do Turismo ABAV 90. Porto Alegre: EPATUR, 1990? [textos de Luiz Carlos Barbosa].

PORTO ALEGRE. SMIC/ESTUR. Porto Alegre: guia turístico 2003. Porto Alegre: ESTUR, 2003.

PORTO ALEGRE. SMIC/ESTUR. Turismo Ecológico. Ecological Tourism. Ilha da Pintada Porto Alegre, RS, Brasil. Porto Alegre: ESTur / Mercociudades, 2000?. [texto de Susana Gastal]

PORTO ALEGRE. SMIC/ESTUR. Porto Alegre, aromas, sons, texturas, cores e sabores. Porto Alegre, aromas, sonidos. Porto Alegre: ESTur, inverno 2000. [texto de Susana Gastal]

PORTO ALEGRE. EPATUR S/A.. Porto Alegre Terra Gente. 2a. ed. Porto Alegre: EPATUR, 1977. [texto de Luiz Carlos Barbosa Lessa]

PORTO ALEGRE. EPATUR S/A. Mapa Panorâmico de Porto Alegre. Assumindo a condição de capital do Mercosul. Porto Alegre: EPATUR, 1993-1996?.

PORTO ALEGRE. SMTUR. Turismo/ Tourism Porto Alegre. Porto Alegre: SMTur / Aracruz, 2007. [texto de Eliana Zarpelon]

PORTO ALEGRE. SMTUR. Panorama de Ações. Porto Alegre. 2017.

RIO GRANDE DO SUL. Catálogo da Exposição do Centenário Farroupilha. Porto Alegre: STAR, 1935.

SELBY, M. Undestanding urban tourism: image, culture and experience. Nova lorque: I. B. Tauris, 2004. 
SINGER, P. Porto Alegre. In: SINGER, P. Desenvolvimento econômico e evolução urbana. São Paulo: Companhia Editora Nacional, 1968.

SMITH, H. The Naturalist Brazilian Expedition. Paper I - From Rio de Janeiro to Porto Alegre. The American Naturalist, v.17, abril 1883. Disponível em: http://www.jstor.org/stable/2449823 Acesso: 26 jan 2018.

SPIROU, C. Urban tourism and urban change: cities in a global economy. New York: Routledge, 2011.

STRAUSS, J. \& CORBIN, A. Pesquisa Qualitativa: técnicas e procedimentos para o desenvolvimento de teoria fundamentada. Porto Alegre: Artmed, 2008.
TOURING CLUB SEÇÃO PORTO ALEGRE. Guia turístico de Porto Alegre. Porto Alegre: Globo, 1955.

URBAIN, J. D. L'idiot du voyage: histoires du touriste. Paris: Payot, 2002.

URRY, J. O Olhar do Turista. São Paulo: SENAC, 2001.

VILLAÇA, F. Espaço intra-urbano no Brasil. São Paulo: Studio Novel/ FAPESP/ Lincoln Institute, 2001.

VIOLIER, P. Tourisme et développement local. Paris: Belin, 2008.

VIOLIER, P.; ZARATE, M. Politiques urbaines du tourisme. In: DUHAMEL, P.; KNAFOU, R. Mondes Urbains du Tourisme. Paris: Belin, 2007.

\section{Processo Editorial / Editorial Process}

Editor Chefe/Editor-in-chief: PhD Thiago D. Pimentel (UFJF).

Recebido em 08 de Fevereiro de 2018; aceito em 15 de Junho de 2018; publicado online em 09 de Julho de 2018.

Received on February 08, 2018; accepted on June 15, 2018, published online on July 09, 2018.

Artigo original / Original article. Seção revisada por pares / Double bind review section. 